\title{
Impaired Dendritic Development and Memory in Sorbs2 Knock-Out Mice
}

\author{
Qiangge Zhang, ${ }^{1,3 \star}$ Xian Gao, ${ }^{1,2,3 \star}$ Chenchen Li, ${ }^{1,3 \star}$ Catia Feliciano, ${ }^{4}$ Dongqing Wang, ${ }^{1}$ Dingxi Zhou, ${ }^{1,5}$ Yuan Mei, ${ }^{1}$ \\ Patricia Monteiro, ${ }^{1,3}$ Michelle Anand, ${ }^{1}$ Shigeyoshi Itohara, ${ }^{6}$ Xiaowei Dong, ${ }^{2}$ Zhanyan Fu, ${ }^{1,3}$ and Guoping Feng ${ }^{1,2,3}$ \\ ${ }^{1}$ McGovern Institute for Brain Research, Department of Brain and Cognitive Sciences, Massachusetts Institute of Technology, Cambridge, Massachusetts \\ 02139, ${ }^{2}$ Key Laboratory of Brain Functional Genomics (Ministry of Education and Science and Technology Commission of Shanghai Municipality), Institute \\ of Cognitive Neuroscience, School of Psychology and Cognitive Science, East China Normal University, Shanghai 200062, China, ${ }^{3}$ Stanley Center for \\ Psychiatric Research, Broad Institute of Massachusetts Institute of Technology, and Harvard, Cambridge, Massachusetts 02142, ${ }^{4}$ Champalimaud \\ Neuroscience Programme, Champalimaud Center for the Unknown, Lisbon 1400-038, Portugal, ${ }^{5}$ School of Life Sciences, Peking University, Beijing 100871, \\ China, and ${ }^{6}$ Laboratory of Behavioral Genetics, RIKEN Brain Science Institute, Wako 351-0198, Japan
}

Intellectual disability is a common neurodevelopmental disorder characterized by impaired intellectual and adaptive functioning. Both environmental insults and genetic defects contribute to the etiology of intellectual disability. Copy number variations of SORBS2 have been linked to intellectual disability. However, the neurobiological function of SORBS2 in the brain is unknown. The SORBS2 gene encodes ArgBP2 (Arg/c-Abl kinase binding protein 2) protein in non-neuronal tissues and is alternatively spliced in the brain to encode nArgBP2 protein. We found $\mathrm{ArgBP} 2$ colocalized with F-actin at dendritic spines and growth cones in cultured hippocampal neurons. In the mouse brain, nArgBP2 was highly expressed in the cortex, amygdala, and hippocampus, and enriched in the outer one-third of the molecular layer in dentate gyrus. Genetic deletion of Sorbs 2 in mice led to reduced dendritic complexity and decreased frequency of AMPAR-miniature spontaneous EPSCs in dentate gyrus granule cells. Behavioral characterization revealed that Sorbs 2 deletion led to a reduced acoustic startle response, and defective long-term object recognition memory and contextual fear memory. Together, our findings demonstrate, for the first time, an important role for nArgBP2 in neuronal dendritic development and excitatory synaptic transmission, which may thus inform exploration of neurobiological basis of SORBS2 deficiency in intellectual disability.

Key words: dendrites; dentate gyrus; intellectual disability; learning and memory; nArgBP2; Sorbs2

Significance Statement

Copy number variations of the SORBS2 gene are linked to intellectual disability, but the neurobiological mechanisms are unknown. We found that nArgBP2, the only neuronal isoform encoded by SORBS2, colocalizes with F-actin at neuronal dendritic growth cones and spines. nArgBP2 is highly expressed in the cortex, amygdala, and dentate gyrus in the mouse brain. Genetic deletion of Sorbs 2 in mice leads to impaired dendritic complexity and reduced excitatory synaptic transmission in dentate gyrus granule cells, accompanied by behavioral deficits in acoustic startle response and long-term memory. This is the first study of Sorbs 2 function in the brain, and our findings may facilitate the study of neurobiological mechanisms underlying SORBS2 deficiency in the development of intellectual disability.

\section{Introduction}

Intellectual disability (ID), formerly known as mental retardation, is a common neurodevelopmental disorder characterized by

Received July 2, 2015; revised Dec. 21, 2015; accepted Jan. 13, 2016.

Author contributions: Q.Z., X.G., C.L., C.F., Y.M., P.M., Z.F., and G.F. designed research; Q.Z., X.G., C.L., C.F., D.W., Y.M., P.M., M.A., Z.F., and D.Z. performed research; S.I. and X.D. contributed unpublished reagents/analytic tools; Q.Z., X.G., C.L., M.A., Z.F., and D.Z. analyzed data; Q.Z., X.G., C.L., and G.F. wrote the paper.

This work was supported by Poitras Center for Affective Disorders at Massachusetts Institute of Technology, Stanley Center for Psychiatric Research at Broad Institute of Massachusetts Institute of Technology, and Harvard, Duke Institute for Brain Sciences, National Institutes of Health/National Institute of Mental Health R01MH081201 to G.F., X.G. was supported by Stanley Center for Psychiatric Research at Broad Institute of Massachusetts, Institute of significantly reduced intellectual abilities and impaired adaptive function (American Psychiatric Association, 2013). ID is estimated to affect $\sim 2 \%-3 \%$ of the population worldwide, with the etiology related to both environmental insults and genetic defects (van Bokhoven, 2011). Despite broad genetic heterogeneity, a growing number of ID risk genes are converging on common

Technology, Harvard, and China Scholarship Council graduate fellowship. Y.M. was supported by National Science Foundation Graduate Fellowship and Integrative Neuronal Systems. P.M. was supported by the Stanley Center for Psychiatric Research at the Broad Institute of Massachusetts Institute of Technology, Harvard, and Portuguese Foundation for Science and Technology doctoral fellowship SFRH/BD/33894/2009. Z.F. was supported by Stanley Center for Psychiatric Research at Broad Institute of Massachusetts Institute of Technology, Harvard, and Brain and 
signaling pathways in regulation of actin cytoskeleton (van Bokhoven, 2011; Pavlowsky et al., 2012). This reflects the fact that actin, as one of the most enriched cytoskeleton proteins, plays important roles in neuronal morphogenesis and structural plasticity (Luo, 2002).

Microdeletions or microduplications of chromosome 4q35.1 in humans have been linked to ID (Rossi et al., 2009). SORBS2 (sorbin and SH3 domain containing 2), also known as ArgBP2 (Arg/c-Abl kinase binding protein 2) (Wang et al., 1997), is one of the candidate genes located in this region that may contribute to the development of cognitive impairments in patients (Rossi et al., 2009). SORBS2, SORBS1 (also known as CAP/Ponsin), and SORBS3 (also known as Vinexin), together constitute a novel adaptor protein family that is characterized by having a sorbin peptide homology (SoHo) domain in their N-terminal region and three Src-homology 3 (SH3) domains in the C-terminal region (Kioka et al., 2002). Through alternative RNA splicing, SORBS2 gene encodes multiple transcripts, including four $\operatorname{ArgBP} 2$ isoforms $(\alpha, \beta, \gamma$, and $\delta$ isoform) and the neuronal isoform, nArgBP2 (Wang et al., 1997; Kawabe et al., 1999; Yuan et al., 2005; Murase et al., 2012). ArgBP2/nArgBP2 isoforms are widely expressed in human tissues and are especially abundant in the brain, heart, pancreas, colon, etc. (Wang et al., 1997). Previous studies revealed that $\operatorname{ArgBP} 2$ colocalizes with actin at cell adhesion sites and stress fibers and interacts with multiple cell adhesion molecules and actin regulators (Kioka et al., 2002; Roignot and Soubeyran, 2009; Anekal et al., 2015). Overexpression of ArgBP2 in cells promotes stress fiber formation, increases cell adhesion, and reduces cell migration (Martin et al., 2013; Anekal et al., 2015), whereas knockdown of ArgBP2 in astrocytes leads to focal adhesion protein dispersion and enhanced peripheral actin ruffling (Cestra et al., 2005). These studies suggest that ArgBP2 functions as an adaptor to coordinate multiple signaling complexes to the regulation of the actin cytoskeleton (Kioka et al., 2002; Roignot and Soubeyran, 2009).

In the brain, $\mathrm{nArgBP} 2$ is the only isoform highly expressed and is characterized by the presence of a neuronal-specific exon (NSE) that is absent in other ArgBP2 isoforms (Kawabe et al., 1999; Cestra et al., 2005). Although nArgBP2 is reported to localize at synapses and interact with the synaptic scaffolding protein SAPAP (Kawabe et al., 1999; Cestra et al., 2005), little is known about nArgBP2 function in brain and whether nArgBP2 deficiency could contribute to ID. In this study, we first characterized nArgBP2 distribution in the developing mouse brain and then investigated $\mathrm{nArgBP} 2$ function in vivo using Sorbs 2 knock-out (KO) mice. We found that nArgBP2 colocalized with F-actin at dendritic growth cones and spines and was highly expressed in the cortex, amygdala, and dentate gyrus (DG) in the mouse brain. Deletion of Sorbs2 in mice reduced dendritic complexity and excitatory synaptic transmission in DG granule cells and impaired acoustic startle response and long-term memory. To-

Behavior Research Foundation National Institute of Mental Health Young Investigator Grant. We thank Sarah Schneck, Sarah Alexander, Morgan Fleishman, and Triana Dalia for technical support; Boaz Barak and Alexandra Krol for critical comments and editing of the manuscript; Michael Lewis for advice on behavioral tests; Anthony J. Koleske for expert advice and sharing reagents; and Mark Bear, Arnold Heynen, and Erik Sklar for help on operant conditioning test.

The authors declare no competing financial interests.

${ }^{*}$ Q.Z., X.G., and C.L. contributed equally to this work.

Correspondence should be addressed to Dr. Guoping Feng, McGovern Institute for Brain Research, Department of Brain and Cognitive Sciences, Massachusetts Institute of Technology, 46 -3143A, 43 Vassar Street, Cambridge, MA 02139. E-mail: fengg@mit.edu.

DOI:10.1523/JNEUROSCI.2528-15.2016

Copyright $\odot 2016$ the authors $\quad 0270-6474 / 16 / 362248-14 \$ 15.00 / 0$ gether, these results revealed an important function of SORBS 2 in the brain and thus may facilitate the study of neurobiological mechanisms underlying SORBS2 deficiency in the development of intellectual disability.

\section{Materials and Methods}

Mice. Sorbs 2 mutant mice were generated by introducing loxP sites to flank the target exon through homology recombination in mouse R1 ES cell by using standard procedures as previously described (Heyer et al., 2012). Exon 12 encoding Sorb C-terminal domain of mouse Sorbs 2 transcript (Ensembl ID: ENSMUST00000171337) was targeted because this exon was predicted to be present in most sorbs 2 transcripts and its deletion would lead to reading frame shift in the following exons, which presumably will cause degradation of Sorbs 2 transcripts through nonsense-mediated mRNA decay (Kervestin and Jacobson, 2012). A targeting vector contains $1 \mathrm{~kb}$ homology arm and a LoxP-Frt-SV40ProNeo-pA-Frt cassette 389 bp upstream of exon 12, and a loxP site with $6 \mathrm{~kb}$ homology arm 676 bp downstream of this exon. This vector was electroporated into mouse R1 ES cells, and correct recombinant clones were selected by PCR screening and further verified by sequencing. One positive ES clone was implanted into C57 blastocysts, and the chimera offspring were either crossed with germline transmittable betaActin-FLP mice (The Jackson Laboratory, stock \#005703) or with germline transmittable betaActin-Cre mice (The Jackson Laboratory, stock \#019099) to produce Sorbs2 floxed mouse line or Sorbs 2 global heterozygote, respectively. Both Sorbs2 mutant lines were backcrossed to C57BL/6J (The Jackson Laboratory, stock \#000664) for $>6$ generations. Sorbs 2 heterozygotes were bred with each other to generate wild-type (WT) and global $\mathrm{KO}$ littermates for all the experiments presented in the work. Primer Sorbs2 GT-F1 (5'CATCGTCATGCTTGTGAAGG 3') and Sorbs2 GT-R1 (5'ATCGAGCTCAGATCTTCAGG3') were paired to detect WT (222 bp) and LoxP (313 bp) alleles; primer pairs of Sorbs2 GT-F1 and Sorbs2 GT-R2 (5'CTGTGGCAACCTTATCATGC3') were used to detect KO (408 bp) allele.

Mice were housed at constant $22^{\circ} \mathrm{C}$, on a $12 \mathrm{~h}$ light/dark cycle with free access to food and water. Each cage contains 2-5 mice regardless of genotype. All experimental procedures were reviewed and approved by the Massachusetts Institute of Technology Committee on Animal Care.

Antibodies. Anti-Sorbs2NSE and anti-Sorbs2C antibodies were produced by using similar strategies as previously described (Welch et al., 2004). Primers Sorbs2NSEAg-F (5'GGGGATGATAGCAAAATGTGTCC3') and Sorbs2NSEAg-R (5'GCGAGTGGGCACCACGTCCC3') were used to amplify cDNA fragment coding the first 201 amino acids of Sorbs2 NSE; primers Sorbs2CAg-F (5'CACGGCAGAGTGGGCATTTTC3') and Sorbs2CAg-R (5'CAGCCTTTTGACATAGTTTCCGG3') were paired to clone the last 195 amino acids of ArgBP2/nArgBP2. These amplified cDNA fragments were then cloned in frame into pET-23b $(+)$ vector to express His-tagged fusion proteins in BL21(DE3) Escherichia coli. Purified His-tagged fusion proteins were used to immunize rabbits to generate polyclonal antibodies, which were further affinity-purified by using Sepharose 4B beads (Sigma) cross-linked with the corresponding antigens. Antibodies against $\alpha$-tubulin (Sigma, T5168), Brn2 (Abcam, ab94977), calretinin (Millipore, AB5054), Ctip2 (Abcam, ab18465), GAPDH (Santa Cruz Biotechnology, sc-32233), Gephyrin (Synaptic System, 147021), GFAP (Sigma, G9269), GFP (Invitrogen, A11122; and Millipore, MAB3580), PSD95 (Thermo Scientific, MA1045), and synaptophysin (Thermo Scientific, 18-0130) are commercially available. Rabbit polyclonal antibodies against NetrinG1 and NetrinG2 were used as previously described (Nishimura-Akiyoshi et al., 2007).

DNA plasmids. Murine full-length cDNA for nArgBP2 was PCR amplified from mouse brain cDNA by using primer nArgBP2FL_SacI_F (5'GC GAGCTCCATGAATACAGATAGCGGTGGG3') and nArgBP2FL_KpnI_ R primer (5'GCGGTACCTCACAGCCTTTTGACATAGTTTCCG3'). PCR fragments were digested to place between SacI and KpnI sites of pEGFP-C2 vector to make GFP-nArgBP2 fusion protein. GFPnArgBP2 $\triangle$ NSE mutant was made by removing NSE from nArgBP 2 through standard molecular cloning techniques. All the plasmids were verified by sequencing. The nArgBP2 cDNA sequence cloned in this study was deposited into GenBank (NCBI GenBank accession number KR610443) because 
we noticed that our sequence is slightly different from a previous cDNA sequence from GenBank (NCBI Reference Sequence NM_00120 5219.1), suggesting the existence of alternative $\mathrm{nArgBP} 2$ isoform in mouse brain.

Cell culture and immunocytochemistry. Low-density hippocampal neurons from P0 mice were cocultured with rat astrocytes in a "sandwich" format at the density of $\sim 12,500$ cells $/ \mathrm{cm}^{2}$ as described previously (Kaech and Banker, 2006). Medium-density $\left(\sim 50,000\right.$ cells $\left./ \mathrm{cm}^{2}\right)$ hippocampal or cortical neurons from P0 mice were cultured on RD German coverslips (Bellco Glass) that were precoated with $20 \mu \mathrm{g} / \mathrm{ml}$ poly-D-lysine (Sigma, P7405) and $4 \mu \mathrm{g} / \mathrm{ml}$ laminin (Invitrogen). Highdensity $\left(\sim 120,000\right.$ cells $\left./ \mathrm{cm}^{2}\right)$ of mouse cortical neurons and astroglia cells were prepared from P0 pups and expanded in tissue culture dishes for preparing cell lysates. Neurons were transfected on DIV4/5 by using Lipofectamine 2000 (Invitrogen).

Neuron cultures were stained as previously described with minor modifications (Zhang et al., 2009). Briefly, cells on coverslips were fixed in PBS containing 4\% PFA and 4\% sucrose for $15 \mathrm{~min}$ at room temperature, permeabilized with $0.2 \%$ Triton X-100 in PBS for $5 \mathrm{~min}$, and followed by blocking with 15\% normal goat serum, 5\% BSA and $0.02 \%$ Tween 20 in PBS for $1 \mathrm{~h}$. Primary antibodies diluted in blocking buffer were applied to fixed cells overnight at $4^{\circ} \mathrm{C}$, followed by washing four times with blocking buffer at the interval of $5 \mathrm{~min}$, and revealed by AlexaFluor-conjugated secondary antibodies (1:1000 dilution in blocking buffer, Invitrogen). DAPI (Sigma) was used to reveal nucleus. Coverslips were mounted on glass slides with ProLong Gold Antifade Mountant (Invitrogen) or Fluoro-Gel (Electron Microscopy Sciences) before imaging. Olympus Fluoview FV1000 confocal microscope with $60 \times$ objective lens (UPlanSApo, 1.35 oil) was used to capture images at the size of $1024 \times 1024$ pixels. $Z$-stack images were acquired at $0.50 \mu \mathrm{m}$ interval for a total depth of $2 \mu \mathrm{m}$. Maximum intensity projections were then formed from the $Z$-stacks.

Immunohistochemistry. Mice were deeply anesthetized with isoflurane and transcardially perfused with PBS solution followed by $4 \%$ paraformaldehyde (PFA) in PBS. Brains were dissected out and kept in 4\% PFA in PBS overnight at $4^{\circ} \mathrm{C}$. Fixed brains were either directly sliced at $50-100$ $\mu \mathrm{m}$ thickness by using Vibratome machine or further cryoprotected with $30 \%(\mathrm{w} / \mathrm{v}$ ) sucrose and O.C.T. (Sakura) before being sectioned by using cryostat machine (Leica, CM1850). For immunohistochemistry, floating brain slices were washed once with PBS and then permeabilized with $0.5 \%$ Triton X-100 in PBS for 30 min at room temperature, followed with blocking in $15 \%$ normal goat serum, 5\% BSA, $0.2 \%$ Triton X-100 in PBS for $1 \mathrm{~h}$ at room temperature. Primary antibodies diluted in blocking buffer were applied to sections overnight at $4^{\circ} \mathrm{C}$. Slices were then washed four times with $0.1 \%$ Tween 20 in PBS for 15 min each and stained with secondary antibodies conjugated with Alexa488/555/647 (Invitrogen) for $2 \mathrm{~h}$ at room temperature or overnight at $4^{\circ} \mathrm{C}$, followed by DAPI staining in PBS for $15 \mathrm{~min}$. Slices were further washed three times with $0.1 \%$ Tween 20 in PBS and one time with PBS. VECTASHIELD mounting medium (Vector Laboratories) or Fluoro-Gel (Electron Microscopy Sciences) was used to mount slices on glass slides. Images were captured by using Olympus Fluoview FV1000 confocal microscope.

Tissue lysate preparation and immunoblotting. The lysates of GFPnArgBP2 or GFP-nArgBP2 $\mathrm{NSE}$ transfected HEK293T cells, cortical neurons, and astroglia cells were prepared in a similar way. Briefly, cell cultures were washed once with ice-cold PBS and lysed in cold RIPA buffer containing protease inhibitors (cOmplete protease inhibitor mixture tablets, Roche) and phosphatase inhibitors (PhosSTOP, phosphatase inhibitor mixture tablet, Roche). Cell lysates were further subjected to brief sonication before centrifugation at $13,200 \mathrm{rpm}$ at $4^{\circ} \mathrm{C}$ for $5 \mathrm{~min}$. Supernatants were collected for BCA protein quantification (Pierce), and equal amount of proteins were subjected to SDS-PAGE (Bio-Rad). To collect mouse tissues, mice were deeply anesthetized with isoflurane and transcardially perfused with ice-cold PBS solution to remove blood. Brain and heart tissues were quickly dissected and snap frozen in liquid nitrogen before storing in $-80^{\circ} \mathrm{C}$. Mouse tissue lysates were prepared by using Dounce Tissue Grinder (Wheaton) and RIPA buffer containing protease and phosphatase inhibitors. Tissue extracts were centrifuged at $13,200 \mathrm{rpm}$ at $4^{\circ} \mathrm{C}$ for $10 \mathrm{~min}$ before collecting supernatant. Equal amount of proteins were separated on SDS-PAGE and transferred to nitrocellulose membranes (Whatman). The membranes were then blocked with $5 \%(\mathrm{w} / \mathrm{v})$ nonfat milk (Millipore) in TBS for $1 \mathrm{~h}$ at room temperature. Primary antibodies were diluted in 5\% nonfat milk in TBST (TBS plus $0.05 \%$ Tween 20) and incubated with the membranes at $4^{\circ} \mathrm{C}$ overnight. Excess antibodies were removed by washing membranes in TBST 4 times for 15 min each at room temperature. Secondary antibodies conjugated with IRDye 680/800 were diluted in Odyssey blocking buffer and applied to the membranes for $1 \mathrm{~h}$ at room temperature. After another extensive washing with TBST, membranes were imaged on ODYSSEY CLx machine (Li-COR).

Lentivirus production and transcranial injection. The ubiquitin promoter in lentivirus vector FUGW (Lois et al., 2002) was replaced with human synapsin-1 promoter to confer neuronal specificity (Glover et al., 2002). P2A-iCre cassette was cloned into the modified vector to express GFP-P2A-iCre fusion protein. Concentrated viral particles expressing GFP or GFP-P2A-iCre were produced as previously described (Welch et al., 2007), and $0.5 \mu \mathrm{l}$ of each virus was transcranially injected into the DG of adult mice following the same procedures as reported previously (Barak et al., 2013).

Morphological characterization of dendritic trees and spines. Previous studies demonstrate that adeno-associated virus (AAV) with serotype 2/9 can cross the blood-brain barrier to infect neurons (Foust et al., 2009), and EGFP with membrane-targeting signal (EGFPf) (Hancock et al., 1991) can promote spine labeling (Cai et al., 2013). Based on these findings, we developed a viral-based method to sparsely label neurons with EGFP. Briefly, the backbone of AAV viral vector pAAV-EF1a-DIOChR2-EYFP-WPRE-HGHpA (Gunaydin et al., 2010) was used to make pAAV-hSyn1-EGFP-P2A-EGFPf-WPRE-HGHpA vector, in which human synapsin-1 promoter drives the expression of EGFP and membrane-targeted EGFPf (Hancock et al., 1991) linked by self-cleaving P2A peptide (Kim et al., 2011). Purified viral particles were generated from this vector with serotype $2 / 9$ by Penn Vector Core at the University of Pennsylvania. To sparsely label the dentate granule cells, $25 \mu \mathrm{l} \mathrm{AAV}$ virus at the titer of $2 \times 10^{12}(\mathrm{GC} / \mathrm{ml})$ in PBS were delivered into mouse cardiovascular system through retro-orbital injection of the venous sinus as previously described (Yardeni et al., 2011). Sorbs2 KO and WT littermates were injected with virus at the age of P14 and killed 3 weeks later for immunohistochemistry. PFA-fixed $200-\mu$ m-thick coronal brain slices were sectioned by using Vibratome machine as mentioned above. Anti-GFP antibody was used to visualize the EGFP-P2A-EGFPf expression. Immunohistochemistry was performed similarly as described earlier, except that $2 \mathrm{~h}$ permeabilization with $0.5 \%$ Triton X-100 in PBS, $48 \mathrm{~h}$ incubation of primary antibody, and $24 \mathrm{~h}$ incubation of secondary antibody were applied to increase the penetrance of antibodies. After staining, each slice was surrounded by a $240-\mu \mathrm{m}$-thick spacer (Electron Microscopy Sciences) and mounted on slides with nonhardening Vectashield mounting medium (Vector Laboratories, catalog \#H-1000).

Olympus Fluoview FV1000 confocal microscope was used to image EGFP-labeled DG granule cells if they were located in the middle of the suprapyramidal blade, and their cell bodies occupied the outer half of the DG granule cell layer from coronal sections $\sim 2.0-2.4 \mathrm{~mm}$ posterior to bregma point. To acquire relatively intact dendritic trees, neurons located around the center in the depth of sections were imaged under $40 \times$ oil lens at $1 \mu \mathrm{m}$ interval for a total thickness of $\sim 100 \mu \mathrm{m}$. Each neuron was manually traced by using Neurolucida software (MBF Bioscience) for $3 \mathrm{D}$ reconstruction and measurements. Dendritic complexity was assessed by using Sholl analysis to examine dendritic intersections per 20 $\mu \mathrm{m}$ concentric radial interval from cell body.

Dendritic segments located at the outer one-third of DG molecular layer were randomly selected for imaging spines. Stack images $(1024 \times$ 1024 pixels) at $150 \mu \mathrm{m}$ interval were acquired by using $60 \times$ oil lens plus $6 \times$ zoom in. Huygens Deconvolution software (Scientific Volume Imaging) was used to process the images. Spines for the imaged dendritic segments were automatically detected and grouped into mushroom, thin, stubby spines by using NeuronStudio software (Rodriguez et al., 2008) with post hoc manual correction.

Experimenters were blinded to genotypes of mice during viral injection, imaging, and measurement analyses. Similar numbers of male and 
female mice from each genotype were used for the analysis of dendritic complexity and dendritic spines.

Electrophysiological studies. The 5-week-old mice were used for the whole-cell electrophysiology procedures. Plasticity experiments were performed on 3- to 4-week-old mice. Experimenters were blinded to mouse genotypes during the recordings and data analysis. Acute horizontal hippocampal slices were prepared as previously described (Laplagne et al., 2006). Briefly, mice were anesthetized with Avertin solution $(20 \mathrm{mg} / \mathrm{ml}, 0.5 \mathrm{mg} / \mathrm{g}$ body weight $)$ and transcardially perfused with 15-20 ml ice-cold carbongenated $\left(95 \% \mathrm{O}_{2}, 5 \% \mathrm{CO}_{2}\right)$ cutting solution containing the following (in $\mathrm{mM}$ ): 194 sucrose, $30 \mathrm{NaCl}, 4.5 \mathrm{KCl}, 1.2$ $\mathrm{NaH}_{2} \mathrm{PO}_{4}, 0.2 \mathrm{CaCl}_{2}, 2 \mathrm{MgCl}_{2}, 26 \mathrm{NaHCO}_{3}$, and $10 \mathrm{D}-(+)$-glucose (with osmolarity of $340-350 \mathrm{mOsm})$. The brains were then rapidly removed and placed in ice-cold cutting solution for slice preparation. The horizontal slices with a subtle angle $\left(20^{\circ}-30^{\circ}\right.$ off the horizontal axis, $\left.300 \mu \mathrm{m}\right)$ were prepared using a slicer (VT1200S, Leica Microsystems) and then incubated in a holding chamber (BSK4, Scientific System Design) at $32^{\circ} \mathrm{C}$ for 10-15 min with carbogenated aCSF as follows (in $\mathrm{mm}$ ): $119 \mathrm{NaCl}, 2.3$ $\mathrm{KCl}, 1.0 \mathrm{NaH}_{2} \mathrm{PO}_{4}, 26 \mathrm{NaHCO}_{3}, 11$ glucose, $1.3 \mathrm{MgSO}_{4}, 2.5 \mathrm{CaCl}_{2}(\mathrm{pH}$ 7.4 , with osmolarity of $295-305 \mathrm{mOsm}$ ). The slices were then transferred to the carbongenated aCSF at room temperature for at least $1 \mathrm{~h}$. Before the recordings, the slice was placed in a recording chamber (RC-27L, Warner Instruments) and constantly perfused with carbongenated aCSF at room temperature unless specified otherwise. The perfusion rate is at $2.0-3.0 \mathrm{ml} / \mathrm{min}$. Whole-cell patch-clamp recordings from dorsal DG were performed with IR-DIC visualized guide. Recording pipettes (KG33, King Precision Glass) were pulled in a horizontal pipette puller (P-97, Sutter Instruments) with a tip resistance of $3-5 \mathrm{M} \Omega$. The pipettes were filled with the internal solution containing the following (in $\mathrm{mm}$ ): $110 \mathrm{CsOH}$ (50\% wt), D-gluconic acid (49\%-53\% wt), $4 \mathrm{NaCl}, 15 \mathrm{KCl}, 5$ TEA-Cl, 20 HEPES, 0.2 EGTA, 5 lidocaine $\mathrm{N}$-ethyl chloride, 4 ATP magnesium salt, and 0.3 GTP sodium salt. $\mathrm{pH}$ was adjusted to $7.2-7.3$ with $\mathrm{KOH}$, and osmolarity was adjusted to $298-300 \mathrm{mOsm}$ with $15 \mathrm{~mm}$ $\mathrm{K}_{2} \mathrm{SO}_{4}$. Cells in which the series resistance (Rs, typically 8-12 $\mathrm{M} \Omega$ ) changed by $>20 \%$ were excluded for data analysis. In addition, cells with Rs $>20 \mathrm{M} \Omega$ at any time during the recordings were discarded. Cell membrane potential was held $-70 \mathrm{mV}$ with a Multiclamp 700B amplifier (Molecular Devices). Signals were low-pass filtered at $2 \mathrm{kHz}$ and sampled at $10 \mathrm{kHz}$ with a Digidata $1440 \mathrm{~A}$ (Molecular Devices), and data were stored on a computer for subsequent off-line analysis.

To record AMPA miniature EPSCs (mEPSCs), the cells were held at $-70 \mathrm{mV}$ in the presence of $50 \mu \mathrm{M}$ DL-APV, $100 \mu \mathrm{M}$ picrotoxin, and 1 $\mu \mathrm{M}$ TTX (all from Tocris Bioscience). The miniature events were not recorded until $5 \mathrm{~min}$ after entering whole-cell patch-clamp recording mode to allow the dialysis of $\mathrm{Cs}^{+}$internal solution for a relatively complete block of the potassium channels in the DG granule cells. The mEPSCs were detected and analyzed with MiniAnalysis (Synaptosoft).

For paired-pulse stimulation (PPR) experiments, AMPAR-mediated EPSCs were evoked by a local concentric bipolar stimulating electrode (CBARC75, FHC). Recordings were made in the presence of picrotoxin $(100 \mu \mathrm{M})$ and DL-APV $(50 \mu \mathrm{M})$ to block activation of $\mathrm{GABA}_{\mathrm{A}}$ receptors and NMDA receptors. Stimulation was current-controlled (ISO-Flex, AMPI). The stimulus intensity was set at a level that could evoke 200-300 pA of AMPAR-mediated response for all the cells measured and delivered with an interstimulus interval of $50 \mathrm{~ms}$. Paired-pulse measurements were obtained for 15 consecutive traces, and only those traces with stable evoked first current response were used for data analysis. The PPR was calculated with the peak current response to the second pulse divided by that of the first response.

Field EPSPs (fEPSPs) were recorded with glass electrodes filled with $2 \mathrm{M} \mathrm{NaCl}$ and were evoked every $30 \mathrm{~s}$ with a local concentric bipolar stimulating electrode (CBARC75, FHC), which was placed at the lateral perforant path in the DG. Stimulation strength was set to a level that evokes $30 \%-40 \%$ of the maximum slope of fEPSP. LTP was induced by a burst stimulation protocol consisting of a total of 80 stimuli as 20 discrete bursts of four stimuli that allows constant and substantially less decline following stimulation as Grover et al. (2009) described. Briefly, a 15 min baseline recording period preceded burst stimulation, and the slices that failed to show stable fEPSP slopes during this period were excluded from further analysis. Burst intervals were $500 \mathrm{~ms}$; stimuli within bursts were always delivered at $10 \mathrm{~ms}$ intervals $(100 \mathrm{~Hz}$ ) (Grover et al., 2009). LTP was quantified by comparing the mean fEPSP slope over the 25-30 min after burst stimulation with the mean fEPSP slope during the baseline period and calculated the percentage change from baseline. For LTD experiments, the stimulus intensity that evokes $40 \%-50 \%$ of the maximum response of fEPSP was set. A low-frequency stimulation (LFS) protocol ( $1 \mathrm{~Hz}, 900$ pulses, $15 \mathrm{~min}$ ) was used for induction of LTD. LTD was quantified by comparing the mean fEPSP slope over the $30 \mathrm{~min}$ after LFS with the mean fEPSP slope during the baseline period and calculated the percentage change from baseline.

Behavioral test. Sorbs2 WT and KO littermates were produced from heterozygous breeding pairs, and $2-5$ mice were housed in the same cage regardless of genotype. Only male mice $\sim 2-4$-months of age were used for behavioral assays, which were conducted during the light phase. Experimenters were blinded to mouse genotypes during all tests and data analyses.

Open field. Spontaneous locomotion was measured by placing mouse in a Plexiglas box $40 \mathrm{~cm} \times 40 \mathrm{~cm} \times 30 \mathrm{~cm}(\mathrm{WLH})$ for $1 \mathrm{~h}$. Motor activity was detected by infrared photobeam sensors and analyzed by VersaMax animal activity monitoring system (AccuScan Instruments).

Elevated zero maze. The test was performed as previously described (Peça et al., 2011). Briefly, mouse was placed in the close arm of an elevated zero maze and video-recorded for $5 \mathrm{~min}$. The duration that mouse stayed in the open-arm was coded by an observer blinded to the mouse genotype.

Acoustic startle threshold and prepulse inhibition (PPI) test. Startle Reflect Station (Kinder Scientific) was used to perform the test. Mice were habituated in startle chambers and exposed to $65 \mathrm{~dB}$ background white noise for $5 \mathrm{~min}$ at $3 \mathrm{~d}$ before testing. The order of startle threshold test and PPI test was counterbalanced in $2 \mathrm{~d}$ : half of the mice were subjected to either acoustic startle threshold test or PPI test on first day, followed by the other test on the following day. A $65 \mathrm{~dB}$ background white noise was presented continually in both tests. For startle threshold test, each mouse was placed in the chamber 5 min before the start of testing session, which includes a total of 92 stimuli (trials) presented in pseudorandom order, with intertrial intervals ranging from 7 to $23 \mathrm{~s}$. The stimuli include a presentation of 8 pulse-alone trials $(120 \mathrm{~dB}, 40 \mathrm{~ms}$ pulse, four at the beginning and 4 at the end of the session), 77 pulse trials ( 7 each of 70,75 , $80,85,90,95,100,105,110,115$, and $120 \mathrm{~dB}, 40 \mathrm{~ms}$ pulse), and 7 trials each without pulse presentation. In each trial, the response to startle stimulus is measured in Newtons. Startle at each pulse level is averaged across trials for data analysis.

Prepulse inhibition test was performed in a similar way, except that each mouse received a total of 57 stimuli (trials) presented in pseudorandom order, with intertrial intervals ranging from 7 to $23 \mathrm{~s}$. The stimuli include a presentation of 8 pulse-alone trials $(120 \mathrm{~dB}, 40 \mathrm{~ms}$ pulse, four at the beginning and 4 at the end of the session), 35 prepulse trials ( 7 each of $70,75,80,85$, and $90 \mathrm{~dB}, 20 \mathrm{~ms}$ prepulse given $100 \mathrm{~ms}$ before a $120 \mathrm{~dB}, 40$ ms pulse), and 7 trials each without pulse or prepulse presentation. In each trial, the response to startle stimulus was measured in Newtons 65 $\mathrm{ms}$ after the presentation of pulse. This measurement is averaged for each prepulse level within the session. The percentage of PPI expressed within each test session is calculated as follows: [100 - (mean prepulse response/mean pulse response $) \times 100]$. Data are shown as mean \pm SEM and analyzed with two-way ANOVA with Bonferroni's post hoc analysis.

Novel object recognition task. The test was performed as reported before with minor modifications (Kim et al., 2013). Nontransparent Plexiglas boxes $(30 \mathrm{~cm} \times 30 \mathrm{~cm} \times 30 \mathrm{~cm})$ under 25 lux illumination were used as arenas. Novel object recognition test was divided into three 10-min-long sessions separated by $10 \mathrm{~min}$ and $24 \mathrm{~h}$ intervals to test short-term and long-term object recognition memory. Three pairs of objects were used in the test, and naive mice showed no significant innate preference to any of the objects. Test mice were first habituated to the arenas $10 \mathrm{~min}$ daily for 3 consecutive days. On day 4, two identical objects (T1 and T2) were used in the first session and placed $15 \mathrm{~cm}$ away from opposite corners of the arena. Test mice were placed in the boxes to allow free exploration for $10 \mathrm{~min}$ before returning back to home cages. After a $10 \mathrm{~min}$ delay, one of the familiarized objects (T1/T2) was replaced with a novel object (N1) in 
the second session before putting mice back to the arenas. At $24 \mathrm{~h}$ later, the third session was performed by introducing mice back to arenas where the object N1 was replaced with another novel objects (N2). Each session was video-recorded from top view and multiple body points (nose point, body center, and tail base) of mice and analyzed by Ethovison (Noldus). The first $5 \mathrm{~min}$ of each test session was selected for analysis. Close interaction to objects is defined as mouse nose point within $2 \mathrm{~cm}$ close to object, but the body center is $1 \mathrm{~cm}$ away from object (to exclude the events that mice sat on top of the objects). The percentage of time spent in close interaction with novel objects relative to the total time spent in close interaction with both objects was used to generate preference index. Two-tailed unpaired $t$ test was used to compare the preference index between genotypes.

Contextual fear conditioning. NIR Video Fear Conditioning System (Med Associates) was used for assessment of fear learning and memory behavior in mice as previously described (Anagnostaras et al., 2010). Mice were group housed in a holding room separate from the test room and were daily handled $2-3 \mathrm{~d}$ before the test. For contextual fear conditioning, the context consisted of an unmodified chamber $(32 \mathrm{~cm} \times 25$ $\mathrm{cm} \times 25 \mathrm{~cm}$; WLH) with a grid floor (36 stainless steel rods); each rod is $2 \mathrm{~mm}$ diameter and spaced $8 \mathrm{~mm}$ apart. The chamber was illuminated with white light during the test and placed in a sound attenuation box with $65 \mathrm{~dB}$ background noise generated by the fan inside. On training day, mice in the home cage were covered by a black plastic bag and carried into the test room. Each mouse was then placed into the fear conditioning chamber and allowed free exploration for $150 \mathrm{~s}$. A $2 \mathrm{~s} 0.65$ $\mathrm{mA}$ electric shock was then delivered three times at $60 \mathrm{~s}$ interval. At $30 \mathrm{~s}$ after the last shock, mice were removed from chambers to their home cage and returned to the holding room. Chambers were cleaned with $70 \%$ ethanol before and after each trial. At $24 \mathrm{~h}$ later, mice were returned to the previous chambers with the same context, following exactly the same procedure as on the training day. The test was run for $5 \mathrm{~min}$ without delivering foot shock. Recorded videos were analyzed by Video Freeze software (Med Associates). Freezing was defined as motion index $<22$ for $1 \mathrm{~s}$.

Toned fear conditioning. A separate cohort of mice was used for toned fear conditioning. On training day, the test room was illuminated with red light, and context was arranged the same way as contextual fear conditioning, except that no white light was presented during the whole training session. Mice in home cage were carried in a black plastic bag into the test room. Each mouse was then placed into fear conditioning chamber and allowed free exploration for $3 \mathrm{~min}$. A combination of $20 \mathrm{~s}$ tone $(2800 \mathrm{~Hz}, 85 \mathrm{~dB})$ that coterminated with a $2 \mathrm{~s} 0.65 \mathrm{~mA}$ shock was delivered 5 times at a $3 \mathrm{~min}$ interval. At $3 \mathrm{~min}$ after the last shock, mice were collected from chambers to their home cage and returned to the holding room. Chambers were cleaned with $70 \%$ ethanol before and after each trial. At $24 \mathrm{~h}$ later, the test room was illuminated with white light, and each chamber was decorated with smooth white plastic floor and black A-frame ceiling, illuminated with white light and scented with $1 \%$ acetic acid. Mice in the home cage were carried in a white plastic bag into the test room and placed into the fear conditioning chamber. After a 2 min baseline period, a $20 \mathrm{~s}$ tone $(2800 \mathrm{~Hz}, 85 \mathrm{~dB})$ was then delivered 5 times at 3 min interval without delivering foot shock. Freezing time in the baseline period and the average of freezing time in the presentation of tones were used for analysis.

Morris water maze. A circular pool of $120 \mathrm{~cm}$ in diameter was used in the test, with water maintained at $23.0 \pm 0.5^{\circ} \mathrm{C}$ and made opaque by white nontoxic tempera paint (Paint White 5130, Berghausen). The pool was centered in a test room $(2.5 \mathrm{~m} \times 2.5 \mathrm{~m})$ with black curtains on the walls. Depending on test sessions, 4 distinct high-contrast posters, serving as space cues, were either hanged or not on the walls. A round platform of $10 \mathrm{~cm}$ in diameter was positioned $0.5 \mathrm{~cm}$ below water surface. Ethovison software (Noldus) was used to track mice in the maze and analyze data. The test was performed as previously described with minor modifications (Vorhees and Williams, 2006). Mice were first subjected to $2 \mathrm{~d}$ (days 1 and 2) visible platform training with platform position changed daily. During this training, visual cues on the black walls were removed, and a $15 \mathrm{ml}$ falcon tube wrapped with black and white strips was placed on top of the platform. Each mouse received four $90 \mathrm{~s}$ trials separated by $10 \mathrm{~min}$ interval on every training day. In each trial, the mouse was released into the pool facing pool wall at pseudo-random starting positions. After reaching the platform, the mouse was allowed to stay on platform for $15 \mathrm{~s}$ before being moved back to home cage; when it failed to find the platform within $90 \mathrm{~s}$, the mouse was manually placed on the platform for $15 \mathrm{~s}$. After visible platform training session, spacial cues were hanged back on the walls, the $15 \mathrm{ml}$ tube was removed from the platform, and position of the platform was moved to a new quadrant and fixed there through the following $6 \mathrm{~d}$ (day $3-8$ ) of invisible platform training session. Each mouse received 4 trials of training daily as described in the previous session. At $24 \mathrm{~h}$ after the last training (day 9), the platform was removed and $60 \mathrm{~s}$ probe trials were performed after releasing mice at the center of the pool. The daily averaged latency to reach platform of each mouse was used to assess learning progress. Duration that mice stayed in each quadrant in the probe test was used to evaluate the spacial memory. Data were shown as mean \pm SEM and analyzed with one-way ANOVA with Bonferroni's post hoc analysis.

\section{Results}

\section{nArgBP2 colocalizes with F-actin at dendritic growth cones and spines}

To specifically examine $\mathrm{nArgBP} 2$ distribution in neurons, we used the first 201 amino acids of the NSE as an antigen to generate an anti-Sorbs2NSE antibody (Fig. 1A). Western blot analysis confirmed that anti-Sorbs2NSE recognized a GFP-nArgBP2 fusion protein, but not a GFP-nArgBP $2 \Delta$ NSE mutant that lacks the NSE (Fig. $1 B-D$ ). The specificity of the anti-Sorbs2NSE antibody was further confirmed by probing brain homogenates and primary cell cultures from mice that lack nArgBP2 expression (Fig. $3 C, D)$. Consistent with the previously reported mRNA distribution (Kawabe et al., 1999), nArgBP2 protein was only detected in brain tissue (Fig. 3C; and data not shown) and exclusively in neurons (Figs. $1 E, F ; 3 D$ ).

To study the subcellular localization of nArgBP2, we performed immunocytochemistry with the anti-Sorbs2NSE antibody on low-density cultured mouse hippocampal neurons at early [2 DIV (DIV2)] and mature (DIV23) developmental stages. At DIV2, when neurons were actively extending neurites, nArgBP2 colocalized with F-actin (revealed by phalloidin staining) and was highly enriched at dendritic and axonal terminals (Fig. 1E,F), whereas in mature neurons at DIV23, nArgBP2 was mainly enriched in dendrites, not axons (Fig. 1G). Within dendrites, nArgBP2 colocalized with F-actin at dendritic spines and dendritic growth cones (Fig. $1 H$ ). These dendritic nArgBP2positive clusters also colocalized well with the excitatory postsynaptic scaffolding protein PSD95 (Fig. 1I-L) but rarely overlapped with inhibitory postsynaptic scaffolding protein gephyrin (Fig. $1 M-P)$, suggesting that nArgBP2 may have a specific function at excitatory synapses.

The presence of the NSE is the major structural feature that differentiates nArgBP2 from ArgBP2 isoforms (Kawabe et al., 1999). To investigate the function of NSE in nArgBP2, GFP$n A r g B P 2$ and GFP-nArgBP2 $\Delta$ NSE mutants were transfected into medium-density cultured cortical neurons at DIV5 and were examined for their distribution at DIV21 when neurons were mature. Whereas GFP-nArgBP2 fusion protein faithfully recapitulated the distribution of endogenous $\mathrm{nArgBP} 2$ at dendritic spines (Fig. 1Q,R; and data not shown), the GFPnArgBP $2 \Delta$ NSE mutant was less prominent at spines, with a much higher enrichment at the soma and dendritic shafts (Fig. 1S,T), suggesting that NSE is required for $\mathrm{nArgBP} 2$ to efficiently target to dendritic spines. 
A

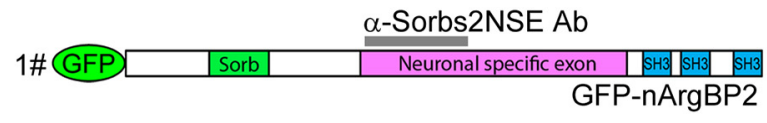
2\# GFP Sorb

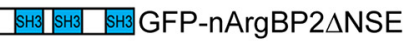
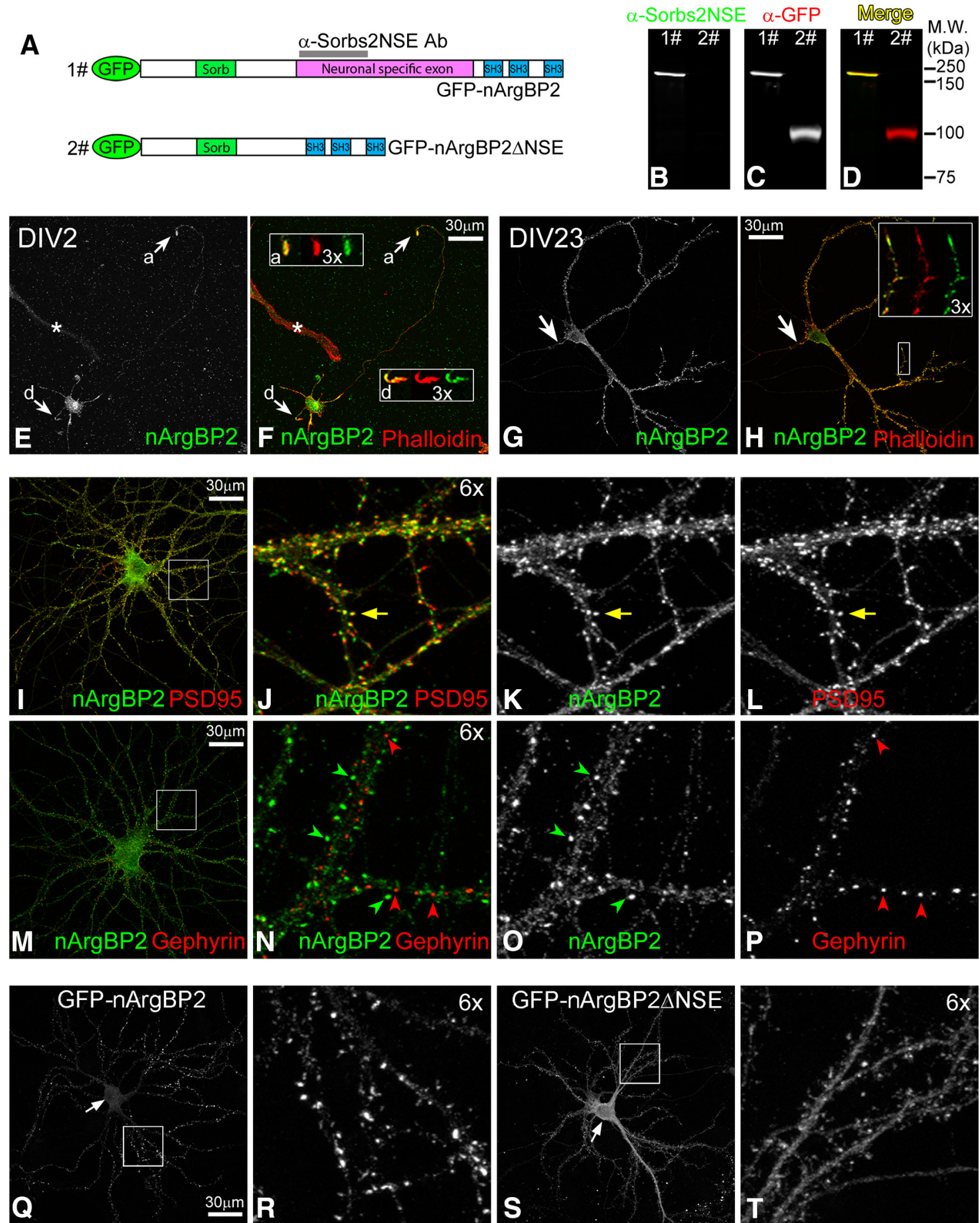

Figure 1. nArgBP2 distribution in cultured neurons. A, Domain diagram of GFP-nArgBP2 and GFP-nArgBP2 $\triangle N S E$ fusion proteins. Sorb, Sorbin homologous domain; SH3, Srchomology 3 domain. Magenta bar represents the position of NSE. Gray bar represents the antigen region used to generate anti-Sorbs2NSE antibody. $\boldsymbol{B}-\boldsymbol{D}$, Anti-Sorbs2NSE antibody specifically recognizes GFP-nArgBP2 (lane 1) but not GFP-nArgBP2 $\triangle N S E$ (lane 2) fusion protein by Western blot. E, F, Localization of nArgBP2 in low-density cultured hippocampal neuron at 2 DIV (DIV2). Arrow and box "a" represent axonal growth cone. Arrow and box "d" represent the dendritic growth cone. Images in the boxes represent $3 \times$ enlarged view of growth cones: merged images (left) of Phalloidin (middle) and nArgBP2 (right). A non-neuronal cell labeled by asterisk shows the background staining from anti-Sorbs2NSE antibody. $\mathbf{G}, \boldsymbol{H}$, Localization of nArgBP2 in low-density cultured hippocampal neuron at DIV23. Arrow indicates axonal initial segment; $3 \times$ magnified view of a dendritic segment shows the colocalization (merged image, left) of Phalloidin (middle) and nArgBP2 (right) at dendritic growth cone and spines. $I-L$, Distribution of nArgBP2 and PSD95 in low-density cultured hippocampal neurons. Yellow arrow indicates the colocalization of nArgBP2 with PSD95. M-P, Distribution of nArgBP2 and Gephyrin in low-density cultured hippocampal neurons. Green and red arrowheads point to puncta enriched with nArgBP2 and Gephyrin, respectively. Q-T, Distribution of exogenous GFP-nArgBP2 and GFP-nArgBP2 $\triangle N$ SE fusion proteins in medium-density cultured cortical neurons. Arrows indicate the position of neuronal cell body, where GFP-nArgBP2 is less enriched than GFP-nArgBP2 $\Delta$ NSE $(\boldsymbol{Q}, \mathbf{S})$. Enlarged boxed regions highlight enrichment of GFP-nArgBP2 at spines $(\boldsymbol{R})$ and have uniform distribution of GFP-nArgBP2 $\Delta$ NSE $(\boldsymbol{T})$.

nArgBP2 is enriched in the cortex, amygdala, and DG in the mouse brain

Next, we investigated nArgBP2 protein expression patterns in the mouse brain using the anti-Sorbs2NSE antibody on serial mouse brain sections. As shown in Figure $2 A$, nArgBP2 is broadly expressed in the mouse brain with high expression level in the cortex, amygdala, and DG, and moderate expression level in striatum, lateral habenula, and thalamus. Within cortical regions, 

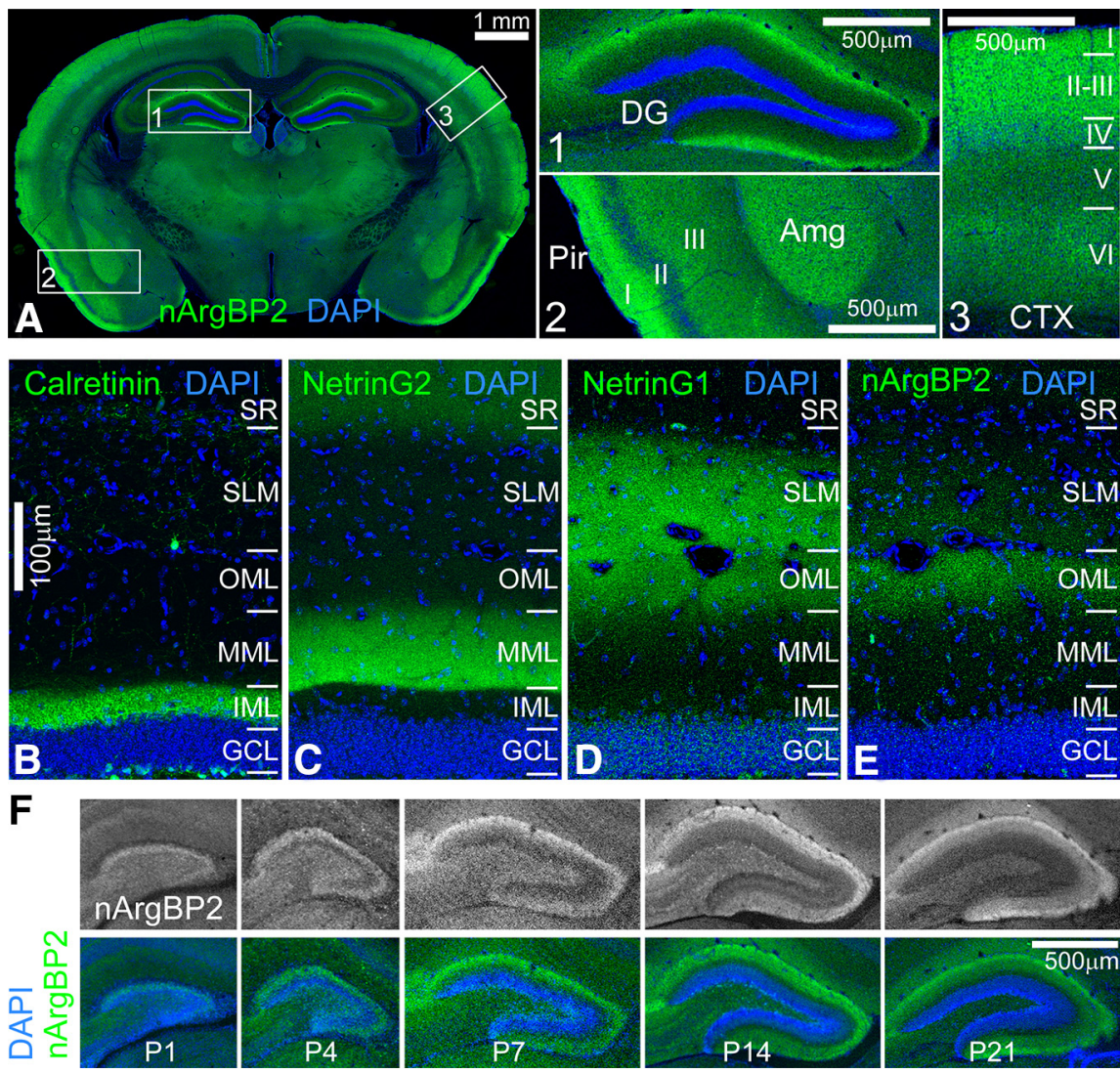

Figure 2. Expression patterns of $n A r g B P 2$ in the mouse brain. $A, A$ coronal section shows expression patterns of $n A r g B P 2$ in the mouse brain. Boxes 1-3 outline brain regions that are magnified. nArgBP2 is highly expressed in the DG molecular layer (Box 1), the amygdala (Amg) and layer l of piriform cortex (Pir) (Box 2), and also layer I-III of neocortex (Box 3). B-E, Comparison with DG inner molecular layer (IML) marker Calretinin (B), medial molecular layer (MML) marker NetrinG2 $(\boldsymbol{C})$, and outer molecular layer (OML) marker NetrinG1 $(\boldsymbol{D})$ reveal that $\mathrm{nArgBP2}$ is enriched in the $\mathrm{OML}(\boldsymbol{E}) . \boldsymbol{F}, \mathrm{nArgBP2}$ distribution in DG during development from $\mathrm{P} 1$ to P21. SR, Stratum radiatum; SLM, stratum lacunosum-moleculare; GCL, granule cell layer.

nArgBP2 immunoreactivity was more intense in layers I-III in the neocortex (Fig. 2A, box 3 ) and layer I of piriform cortex (Fig. 2A, box 2). In the DG, nArgBP2 was specifically enriched at the edge of the molecular layer (Fig. 2A, box 1). Based on afferent axonal inputs, the DG molecular layer is divided into three laminas: outer molecular layer (OML), which receives axonal projection from lateral entorhinal cortex; medial molecular layer, which is innervated by axonal inputs from medial entorhinal cortex; and inner molecular layer, which receives axonal innervation from mossy cells in the contralateral and ipsilateral hilar region (Förster et al., 2006; Witter, 2007). Labeling these layers using layer-specific markers (Nishimura-Akiyoshi et al., 2007) revealed that $\mathrm{nArgBP} 2$ immunoreactivity in DG was mainly restricted to the OML (Fig. $2 B-E$ ). This laminated distribution of nArgBP2 in DG emerged as early as postnatal day 4 (P4) in mice and became more restricted by $\mathrm{P} 21$ and thereafter (Fig. $2 F$ ). nArgBP2 localization paralleled the dendritic growth of DG granule cells (Rahimi and Claiborne, 2007), suggesting that nArgBP2 may play an important role in dendritic development.

\section{Generation of Sorbs $2 \mathrm{KO}$ mice}

To study nArgBP2 function in vivo, we generated Sorbs2 conditional $\mathrm{KO}$ mice by floxing an exon that is conserved in nearly all the ArgBP2/nArgBP2 isoforms (see Materials and Methods; Fig. $3 A)$. Sorbs 2 floxed mice were paired with germline-transmittable Cre transgenic mice to obtain Sorbs2 heterozygotes (Het), which were further paired with each other to generate Sorbs2 KO mice and WT littermates (Fig. 3A,B). Loss of Sorbs2 in mice led to a $\sim 40 \%-60 \%$ mortality in the first postnatal week; however, surviving Sorbs2 KOs had normal body weight and were generally indistinguishable from WT littermates (data not shown). Characterization of Sorbs $2 \mathrm{KO}$ mice confirmed ArgBP2/nArgBP2 proteins were completely lost from both mouse heart and brain tissue as revealed by Western blot analysis using the antiSorbs2C antibody, which recognizes the conserved SH3 domains of ArgBP2 and nArgBP2 proteins (Fig. 3C; see Materials and Methods). We also confirmed loss of nArgBP2 in Sorbs 2 KO mouse brain using the anti-Sorbs2NSE antibody (Fig. 3C). Furthermore, we compared ArgBP2 and nArgBP2 expression in cortical neuronal and astroglial cultures prepared from WT and Sorbs $2 \mathrm{KO}$ mice. As shown in Figure $3 D, \mathrm{nArgBP} 2$ was exclusively detected in WT neuronal cultures and $\operatorname{ArgBP} 2$ was specifically detected in the WT astroglial cultures. Both ArgBP2 and nArgBP2 were absent from Sorbs2 KO neuronal and astroglial cultures.

To assess whether Sorbs2 deletion can affect gross brain structure, we compared the overall brain morphology between WT and Sorbs 2 KO mice using coronal and sagittal sections. As shown in Figure $4 A$, NeuN immunostaining of coronal and sagittal sections was indistinguishable between genotypes. Additionally, $\mathrm{KO}$ brains also exhibited normal cortex and DG molecular layer lamination (Fig. 4B,C). Therefore, these characterizations suggest that overall brain morphology is not affected by Sorbs 2 deficiency.

\section{nArgBP2 is required for dendritic development of DG granule cells}

As shown in Figure 1E, $F, \mathrm{nArgBP} 2$ is present at both axonal and dendritic terminals in cultured neurons. Therefore, the laminated distribution of nArgBP2 in the DG molecular layer could come from presynaptic compartments (i.e., axon terminals projected from lateral entorhinal cortex) or postsynaptic compartments (i.e., dendritic terminals of DG granule cells). To determine the source of $n \mathrm{ArgBP} 2$, we removed $\mathrm{nArgBP} 2$ expression only from local DG neurons, leaving possible expression in axonal terminals intact. We used lentivirus with neuronalspecific promoter to deliver Cre recombinase to the DG neurons in Sorbs2-floxed mice. The use of lentivirus limited expression of Cre recombinase, and loss of Sorbs2, to local neurons in the DG, particularly granule cells, because lentivirus has been shown to transduce neurons mainly through somas but not axons (Gradinaru et al., 2009). Expression of LV-EGFP-P2A-Cre virus by DG granule cells led to the loss of nArgBP2 immunoreactivity (Fig. $5 D-F$ ), indicating that $\mathrm{nArgBP} 2$ is enriched at dendritic terminals of DG granule cells, consistent with nArgBP2 localization at dendritic growth cones in cultured neurons (Fig. $1 E, F$ ).

Because nArgBP2 is highly expressed by DG granule cells (Fig. 2), we asked whether nArgBP2 plays a role in DG granule 


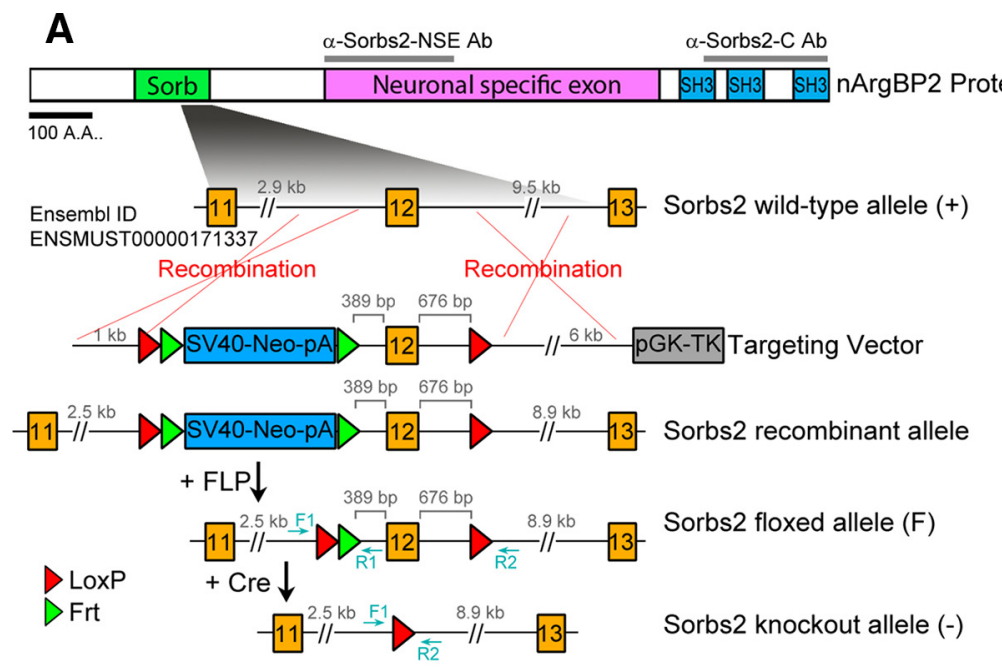

B
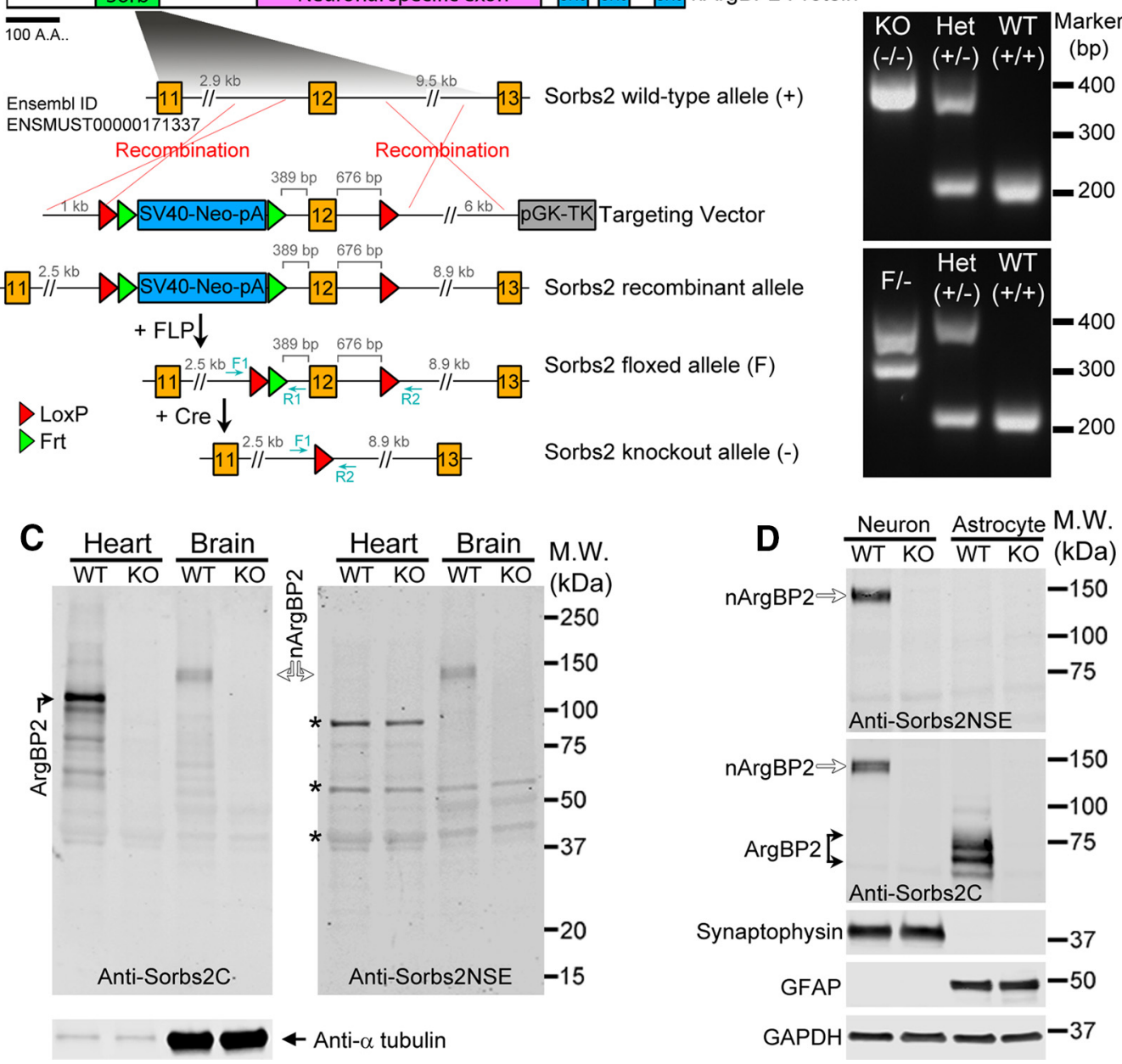

Figure 3. Generation of Sorbs 2 floxed and KO mutant mice. $A$, Exon 12 that encodes part of the Sorb domain was selected for targeting. Thymidine kinase driven by mouse phosphoglycerate kinase 1 promoter ( $\mathrm{pGK-TK)} \mathrm{was} \mathrm{used} \mathrm{for} \mathrm{negative} \mathrm{selection;} \mathrm{neomycin} \mathrm{resistance} \mathrm{gene} \mathrm{driven} \mathrm{by} \mathrm{the} \mathrm{SV40} \mathrm{promoter} \mathrm{(SV40-Neo)} \mathrm{was} \mathrm{used} \mathrm{for} \mathrm{positive} \mathrm{selection.} \mathrm{Transgenic} \mathrm{mice} \mathrm{expressing} \mathrm{germline}$ transmittable FLP and Cre recombinase were crossed with mice containing the Sorbs 2 recombinant allele to generate Sorbs 2 floxed allele (F) and K0 allele ( - ). Primers F1, R1, and R2 were combined for detecting Sorbs 2 mutants and WT. B, PCR genotyping for Sorbs 2 mutants and WT mice. C, Immunoblots show the complete absence of ArgBP2 and nArgBP2 proteins in heart and brain tissues from Sorbs $2 \mathrm{KO}$ mice. Left, Anti-Sorbs 2 C antibody recognizes both ArgBP2 (black arrow) and nArgBP2 (open arrows). Bottom, Anti- $\alpha$ tubulin antibody reveals that similar amounts of proteins were loaded between genotypes. Right, Same amount of tissue homogenates was also probed with anti-Sorbs2NSE antibody. Bands labeled by asterisks were recognized by anti-Sorbs2NSE antibody in both genotypes but not detected by anti-Sorbs 2 Cantibody, suggesting that they were nonspecific signals. D, Immunoblots show that nArgBP2 is exclusively expressed in neuronal cultures, whereas ArgBP2 is only detected in astroglial cells. Both nArgBP2 and ArgBP2 were depleted from neuronal and astroglial cultures derived from Sorbs2 K0 mice. Antibodies against synaptophysin and GFAP were used as markers for neurons and astrocytes, respectively. Anti-GAPDH antibody revealed that similar amounts of proteins were loaded for each lane.

cell dendrite development. To compare dendrite morphology of DG granule cells in Sorbs2 KO and WT mice, we developed a viral-based method to sparsely and clearly label neuronal dendrites and spines with EGFP (Fig. 5G,L). We performed intravenous injections of P14 Sorbs2 KO and WT mice with AAV expressing both cytoplasmic EGFP and membrane-targeting EGFPf under the control of human synapsin-1 promoter (pAAVhSyn1-EGFP-p2A-EGFPf) (further described in Materials and Methods). Characterization of dendrite morphology based on EGFP/EGFPf expression 3 weeks later revealed clear sparse visualization of DG granule cell dendrite (Fig. 5G) and dendritic spine morphology (Fig. 5L). Using this labeling method, we found that dendritic trees of DG granule cells were much less complex in Sorbs2 $\mathrm{KO}$ mice compared with those of WT mice, as revealed by Sholl analysis (Fig. $5 \mathrm{H}, \mathrm{I}$ ). Additionally, total dendritic length (WT: $1491 \pm 60.01 \mu \mathrm{m}, n=17$; KO: $1068 \pm 48.56$ $\mu \mathrm{m}, n=22 ; p<0.0001$; Fig. $5 \mathrm{~J})$ and number of dendritic branch points (WT: $9.2 \pm 0.3, n=17$; KO: $6.7 \pm 0.4, n=22 ; p<0.0001$; Fig. $5 \mathrm{~K}$ ) were all significantly reduced in Sorbs $2 \mathrm{KO}$ mice. Both male and female mice had a similar trend of reduction in DG granule cell dendritic complexity (data not shown). We also characterized the density and shape of dendritic spines in the DG molecular layer but did not observe significant differences between genotypes (Fig. $5 L, M$ ). Together, these results indicate that nArgBP2 plays an important role in dendritic development of DG granule cells.

\section{Excitatory synaptic transmission in DG is reduced in Sorbs2 KO mice}

To determine the functional consequences of nArgBP2 deficiency on synaptic transmission in DG granule cells, we performed whole-cell patch-clamp recording in DG granule cells from acute slices of 5-week-old mice. To study the baseline spontaneous activity of those cells, we examined the frequency and 

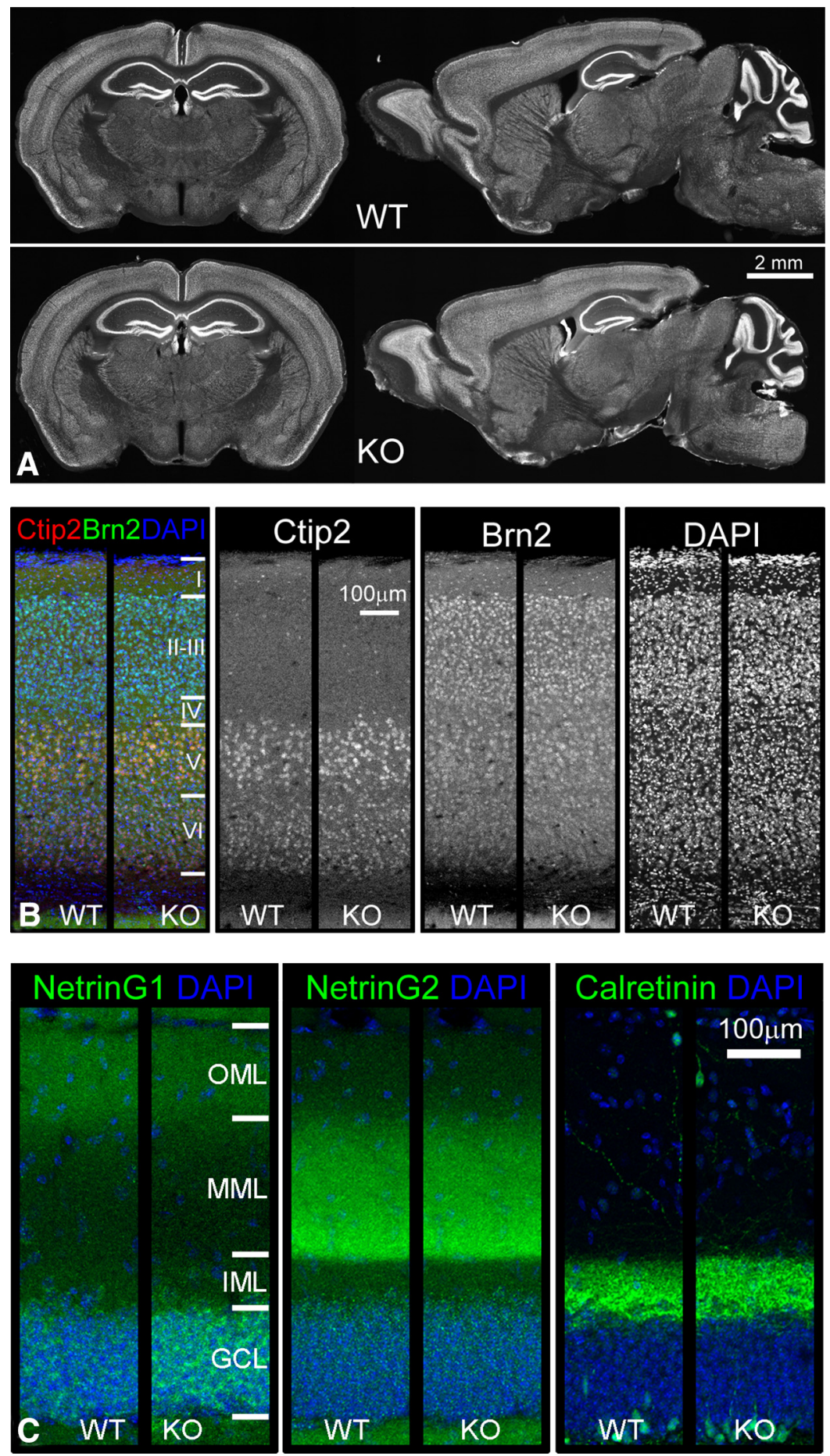

Figure 4. Normal brain morphology and unaltered lamination of cortex and DG molecular layer in Sorbs2 K0 mice. $\boldsymbol{A}$, NeuN immunohistochemistry of coronal and sagittal sections from 3-month-old WT and Sorbs $2 \mathrm{KO}$ mice. $\boldsymbol{B}$, Immunofluorescent staining of cortical layer marker Ctip2 (layer 5 and 6) and Brn2 (layer 2/3 and 5) revealed similar expression patterns in WT and Sorbs 2 K0 mice. C, NetrinG1, NetrinG2, and calretinin immunostaining of DG molecular layers in WT and Sorbs2 KO mice.

of WT littermates (WT: $1.33 \pm 0.10 \mathrm{~Hz}$, $n=26 ; \mathrm{KO}: 0.71 \pm 0.05 \mathrm{~Hz}, n=25 ; p<$ 0.001 ; Fig. $6 C$ ), whereas the mean frequency of mEPSCs in Sorbs2 Het mice was not changed compared with the WT littermates (Het: $1.19 \pm 0.09 \mathrm{~Hz}, n=8 ; p=$ 0.4457; Fig. 6C). In contrast, the amplitude of the mEPSCs in Sorbs $2 \mathrm{KO}$ and Het mice was similar to that of WT littermates (WT: $12.41 \pm 0.31 \mathrm{pA}, n=25 ; \mathrm{KO}$ : $12.81 \pm 0.34 \mathrm{pA}, n=26$; Het: $13.26 \pm$ $0.81 \mathrm{pA}, n=8$; KO vs WT: $p=0.3906$; Het vs WT: $p=0.2426$; Fig. $6 D)$. The reduction in mEPSC frequency suggests either reduced presynaptic release probability or decreased number of functional synapses in DG granule cells from Sorbs2 $\mathrm{KO}$ mice.

Because we showed that $\mathrm{nArgBP} 2$ is highly enriched in the outer one-third of molecular layer in DG (Fig. $2 B-E$ ), which is mainly innervated by lateral perforant path (LPP) input from the lateral entorhinal cortex (Witter, 2007), we chose to focus on the LPP-DG pathway to determine whether Sorbs 2 deletion affects presynaptic release probability. We measured PPR, a short presynaptic form of synaptic plasticity, from LPP input to DG granule cells in brain slices derived from Sorbs $2 \mathrm{KO}$ mice at interpulse intervals of $50 \mathrm{~ms}$. The PPR was comparable between Sorbs2 KO and WT littermates (WT: $1.30 \pm 0.07, n=8$; KO: $1.29 \pm 0.08$, $n=9 ; p=0.9978$; Fig. $6 E-G)$, suggesting that the presynaptic glutamate release probability of LPP was not altered in Sorbs2 KO granule cells. Together with the observations of enrichment of nArgBP2 at dendritic spines (Figs. 1, Fig. 5A-F) and reduced dendritic complexity of DG neurons in Sorbs2 $\mathrm{KO}$ mice (Fig. $5 \mathrm{H}-\mathrm{K}$ ), our finding of the decreased frequency of mEPSCs in Sorbs2 $\mathrm{KO}$ granule cells suggests a decrease in the total number of functional synapses onto KO neurons.

\section{Sorbs 2 KO mice exhibit normal long-} term synaptic plasticity in DG

Long-term synaptic plasticity (LTP/LTD) in hippocampus serves as a molecular substrate for learning and memory processes in the CNS (Bliss and Collingridge, 1993). We thus assessed the effects of Sorbs2 deletion on LTP and LTD in the LPP input to the DG ex vivo. LTP was elic-

amplitude of AMPAR-mediated spontaneous miniature EPSCs (mEPSCs) of DG granule cells from Sorbs2 KO and WT littermates. AMPAR-mEPSCs were recorded with bath application of picrotoxin $(100 \mu \mathrm{M})$, DL-APV $(50 \mu \mathrm{M})$, and TTX $(1 \mu \mathrm{M})$ to block GABA receptor-mediated inhibitory currents, NMDA receptorand action potential-dependent synaptic transmission, respectively. As shown in Figure $6 A-C$, the mean frequency of mEPSCs in Sorbs2 KO mice was significantly reduced compared with that ited by applying a burst electrical stimulation (20 bursts, separated by intervals of $500 \mathrm{~ms}$, with each burst containing four stimuli at $100 \mathrm{~Hz}$ ) of the LPP-DG input. As shown in Figure $6 \mathrm{H}$, WT and Sorbs2 KO mice showed a similar level of LTP (WT: $129 \pm 4 \%, n=8$; KO: $135 \pm 5 \%, n=9 ; p=0.7978$, two-way ANOVA test; Fig. $6 H$ ) that lasted for $>40$ min after the burst stimulation. We then examined the effects of Sorbs 2 deletion on LTD using a low-frequency stimulation protocol $(1 \mathrm{~Hz}, 900$ 
pulses, LFS). As shown in Figure 6I, we did not observe statistically significant differences in LTD between WT and Sorbs2 KO mice, although a small trend of higher level of LTD was observed in Sorbs $2 \mathrm{KO}$ mice (WT: $72 \pm 3 \%, n=11$; KO: $64 \pm 4 \%, n=11 ; p=0.1605$, twoway ANOVA test; Fig. 6I).

\section{Sorbs 2 deletion impaired acoustic} startle response and memory in mice Because mutations of SORBS2 have been linked with ID (Rossi et al., 2009; Fromer et al., 2014; Castellani et al., 2015), we investigated whether Sorbs2 KO mice have any behavioral deficits that may be related to this disorder. To avoid a possible confound of the estrous cycle on the performance of rodent behaviors (Markus and Zecevic, 1997; Jasnow et al., 2006; van Goethem et al., 2012), we limited our behavioral analysis to male 2.5- to 4-month-old WT and Sorbs2 KO littermates. Sorbs $2 \mathrm{KO}$ and WT mice were first subjected to open-field and elevated zero-maze tests. As shown in Figure $7 A, B$, the locomotion activity and anxiety level were comparable between genotypes.

Deficits in sensorimotor gating are common in neurodevelopmental disorders (Osumi et al., 2015). In addition, SORBS2 de novo mutations have also been found in schizophrenia patients (Fromer et al., 2014), which often have sensorimotor gating deficits as measured by PPI. Interestingly, we found that, in the acoustic PPI test, the performance of Sorbs $2 \mathrm{KO}$ mice was significantly impaired (Fig. 7D). However, interpretation of PPI deficits in Sorbs2 $\mathrm{KO}$ mice is complicated by the profound defects also found in acoustic startle response test (Fig. $7 C$ ).

Learning and memory deficits are common recognizable manifestations of ID (American Psychiatric Association, 2013). Based on the high expression of $\mathrm{nArgBP} 2$ in the cortex, amygdala, and DG, we chose the novel object recognition test (Antunes and Biala, 2012), toned fear conditioning test, contextual fear conditioning test, Morris water maze test, and operant visuospatial discrimination test (Krueger et al., 2011) to characterize cognitive function and learning and memory abilities of Sorbs $2 \mathrm{KO}$ mice.

The novel object recognition test was performed as illustrated in Figure 7E. Mice were first exposed to two identical objects (T1 and T2) for $10 \mathrm{~min}$, allowing them to get familiar with the objects. After a $10 \mathrm{~min}$ delay, one of the familiarized objects (T1/T2) was replaced with a novel object (N1), and mice were tested for their short-term object recognition memory. To assess long-term object recognition memory, a third novel object (N2) was introduced to replace object N1 at tests $24 \mathrm{~h}$ later. Normally, the WT mice are capable of differentiating novel objects from familiar ones and tend to explore novel ones for longer. As shown in Figure $7 F, 10$ min after the familiarization session, Sorbs2 KO mice permean (SEM).
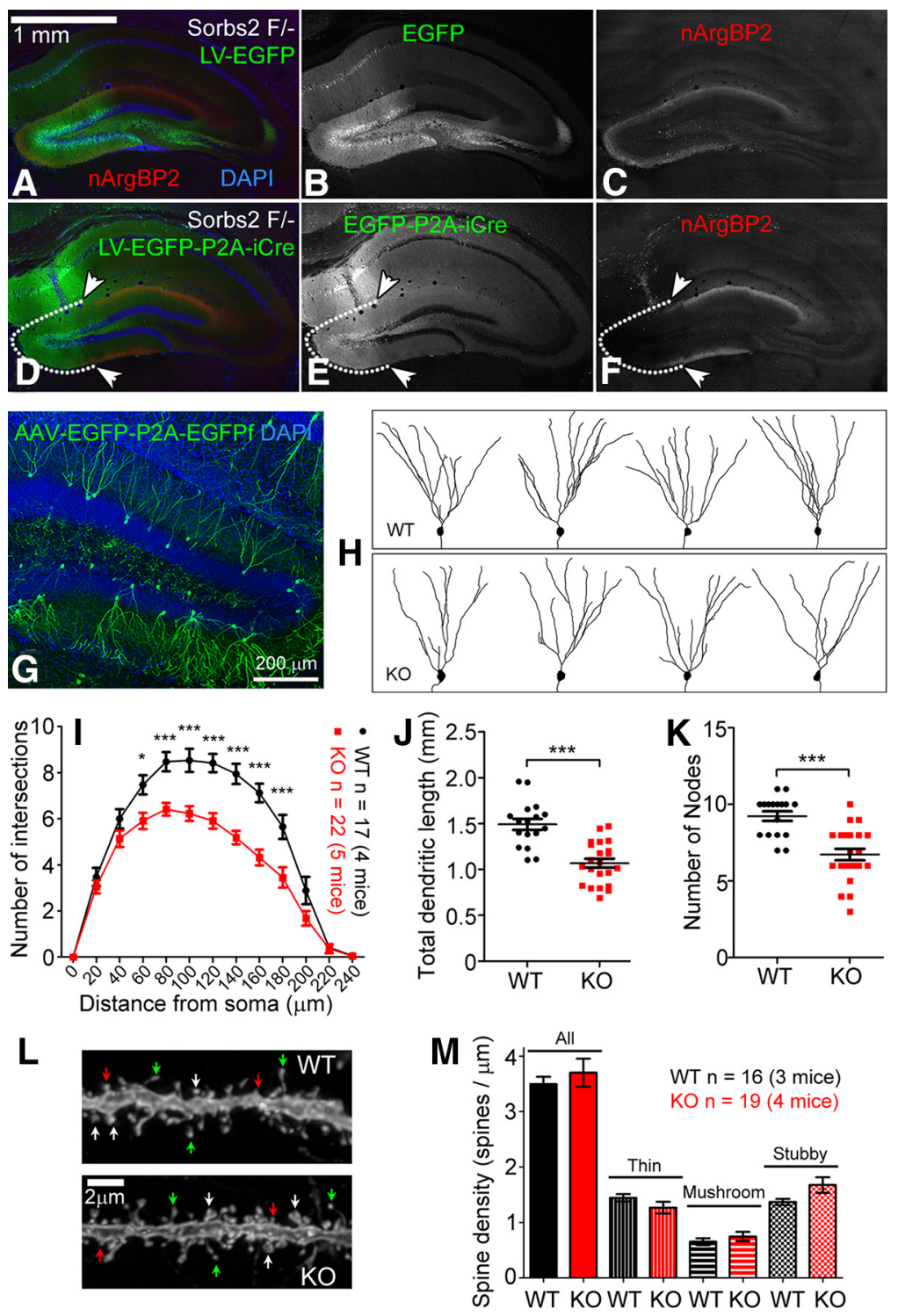

Figure 5. $\mathrm{nArgBP} 2$ is required for normal dendritic development of $D G$ granule cells. $\boldsymbol{A}-\boldsymbol{F}$, Lentiviral expression of iCre recombinase in DG granule cells of Sorbs2 floxed mice (F/-, one floxed allele, and one $K 0$ allele) specifically removed the laminated expression of $\mathrm{nArgBP} 2$ in the $D G$ molecular layer $(\boldsymbol{D}-\boldsymbol{F})$. White dotted line and arrowheads indicate the DG region where iCre was expressed. Lentiviral expression of EGFP had no effect on nArgBP2 expression ( $\boldsymbol{A}-\boldsymbol{C}$ ). G, AAV-EGFP-P2A-EGFPf sparsely labeled DG granule cells after intravenous injection. $\boldsymbol{H}$, Representative images of DG granule cells that were traced according to EGFP/EGFPf expression. I, Sholl analysis indicates reduced dendritic complexity in Sorbs $2 \mathrm{KO}$ mice (two-way ANOVA, shell radius $\times$ genotype: interaction, $p<0.0001$; effect of genotype, $p<0.0001$; effect of shell radius, $p<0.0001$. Bonferroni post hoc test: ${ }^{*} p<0.05$, ${ }^{* * *} p<0.0001 ; \mathrm{WT}: n=17$ neurons of 4 mice, K0: $n=22$ neurons of 5 mice). $J$, Total dendritic length (WT: $1491 \pm 60.01 \mu \mathrm{m}$; K0: $1068 \pm 48.56 \mu \mathrm{m}$; two-tailed $t$ test, ${ }^{* * *} p<0.0001$ ) and $(K)$ number of nodes (WT: $9.2 \pm 0.3 ; \mathrm{K} 0: 6.7 \pm 0.4$; two-tailed $t$ test, ${ }^{* * *} p<0.0001$ ) were also dramatically reduced in $K 0$ mice. $L$, Representative images of dendritic spines of DG granule cells from WT and KO mice. White arrows indicate mushroom spines. Red arrows indicate stubby spines. Green arrows indicate thin spines. $\boldsymbol{M}$, Statistics of spine density revealed no significant differences across genotypes. Error bars indicate standard error of the

formed similarly to WT mice, and both showed significant preference to the novel object (WT: $67.21 \pm 2.51 \%, n=15$; KO: $66.56 \pm$ $2.43 \%, n=16 ; p=0.8547)$; however, compared with WT, Sorbs2 $\mathrm{KO}$ mice showed significantly less preference for the new object after a 24 h delay (WT: $64.04 \pm 3.54 \%, n=15 ; \mathrm{KO}: 54.52 \pm 2.93 \%, n=$ $16 ; p<0.05$; Fig. $7 G$ ). These results suggest that long-term, but not short-term, object recognition memory was affected in Sorbs2 KO mice.

We next assessed contextual memory by subjecting Sorbs $2 \mathrm{KO}$ mice into a contextual fear conditioning test. During the training 

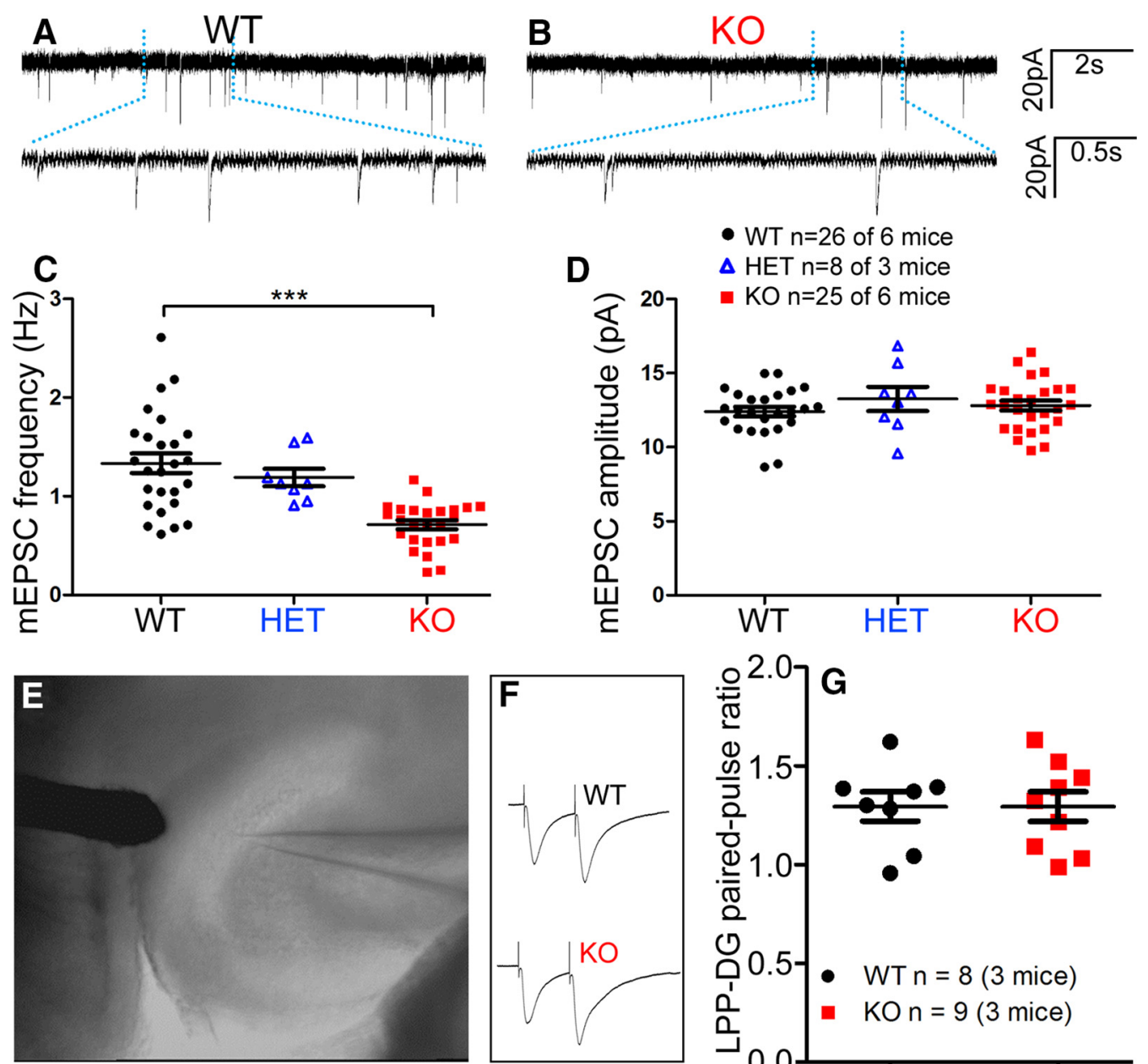

- WT $n=26$ of 6 mice

$\triangle \mathrm{HET} n=8$ of 3 mice

- KO $n=25$ of 6 mice
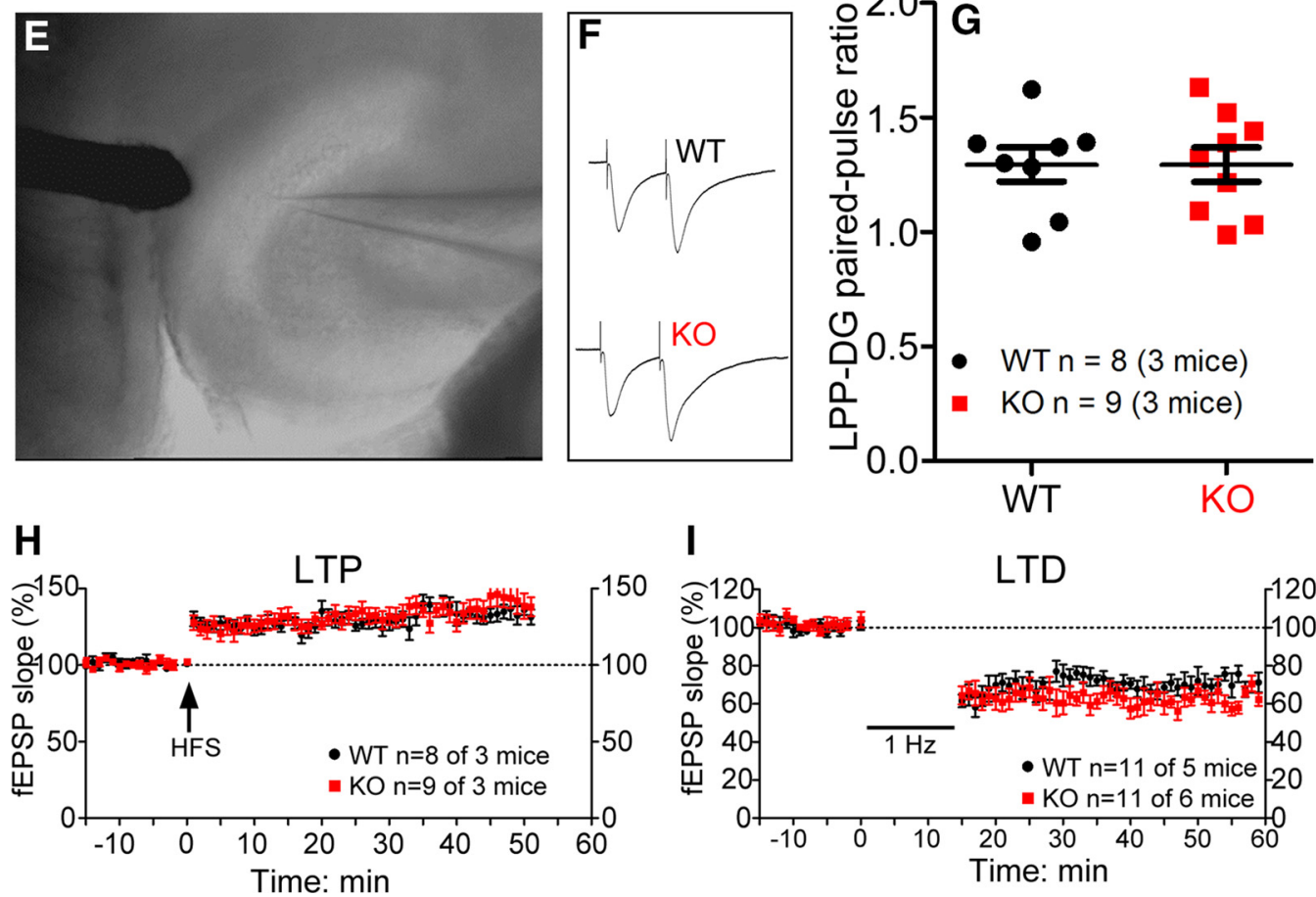

Figure 6. Decreased frequency of mEPSCs in DG granule cells from Sorbs2 $\mathrm{KO}$ mice. $A, B$, Representative traces showing mEPSCs of DG granule cells from WT and Sorbs $2 \mathrm{KO}$ mice, respectively. $C$, $D$, Summarized data demonstrating the reduction in frequency but not amplitude of mEPSCs in Sorbs $2 \mathrm{KO}$ mice (WT: $n=26$ of 6 mice, HET: $n=8$ of 3 mice; K0: $n=25$ of 6 mice). ${ }^{* * *} p<0.0001$ (one-way ANOVA with Bonferroni's post hoc analysis). $\boldsymbol{E}$, Representative hippocampal DG slice showing the position of the concentric bipolar stimulating electrode for the stimulation of the LPP. $\boldsymbol{F}$, Representative traces of evoked EPSCS of DG granule cells from WT and Sorbs $2 \mathrm{KO}$ mice upon paired-pulse stimulation (paired stimuli pulses of $50 \mathrm{~ms}$ interval) of the LPP. G, The paired-pulse ratio in slices of Sorbs $2 \mathrm{KO}$ mice was not different from that of WT mice. $p=0.9978$ (two-tailed $t$ test). $\boldsymbol{H}$, LTP induced by burst high-frequency stimulation (HFS) in slices was comparable between WT and Sorbs $2 \mathrm{KO}$ mice. I, Similar level of LTD were induced in slices from WT and Sorbs $2 \mathrm{KO}$ mice by 900 pulses stimulation delivered at $1 \mathrm{~Hz}$ interval. Error bars indicate SEM.

phase, Sorbs2 KO mice showed similar levels of freezing behavior as WT littermates after being conditioned to aversive electrical shocks (Fig. $7 H$ ). However, when mice were returned to the same context $24 \mathrm{~h}$ after training, Sorbs $2 \mathrm{KO}$ mice showed significantly less freezing time than WT littermates (WT: $33.41 \pm 3.04 \%, n=$ 15 ; KO: $21.61 \pm 3.35 \%, n=14 ; p<0.05$; Fig. $7 I)$, suggesting that contextual fear memory was impaired in Sorbs $2 \mathrm{KO}$ mice. Interestingly, the performances of Sorbs $2 \mathrm{KO}$ mice in the toned fear conditioning test and Morris water maze test were indistinguishable from WT littermate controls (Fig. $7 J-M$ ), suggesting that cued fear memory and spatial memory were not affected by the loss of Sorbs 2 in mice. In addition, Sorbs $2 \mathrm{KO}$ mice behaved similarly as WT mice in the acquisition of a visuospatial discrimination task (data not shown). Together, these results suggest that Sorbs2 KO mice have defects in a subset of cognitive and learning/ memory tests.

\section{Discussion}

Chromosome 4q35 microdeletions/microduplications that cover SORBS2 gene have been found in patients with ID (Rossi et al., 2009). Because these deletions/duplications affect multiple genes, it is unknown whether SORBS2 deficiency contributes to neuro- 
A
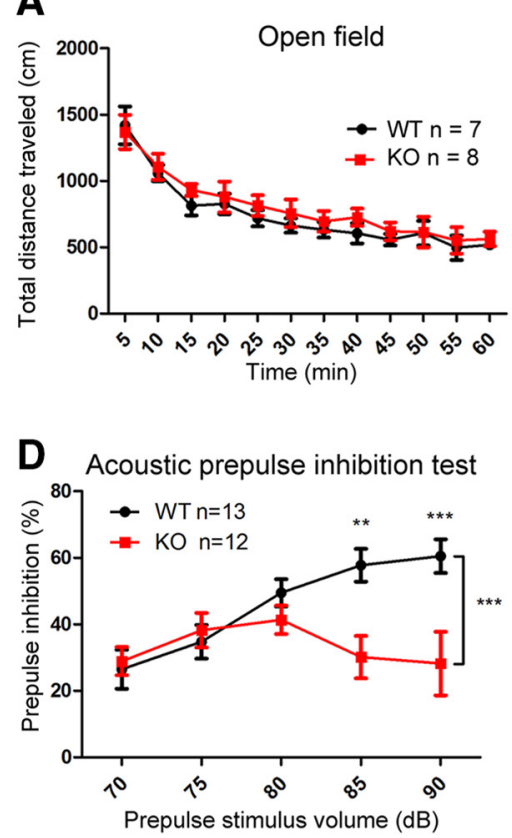

H

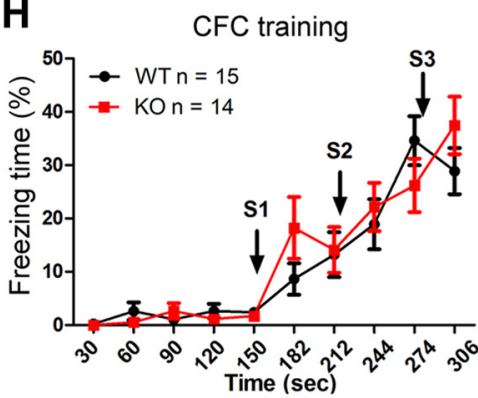

J

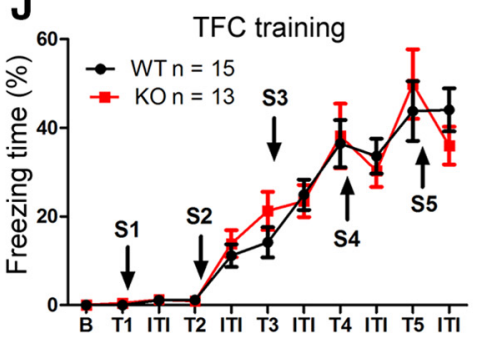

B

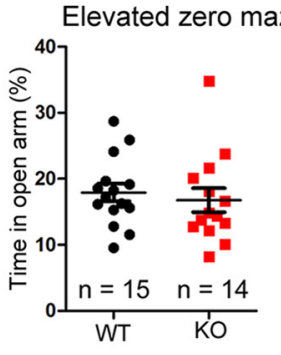

C

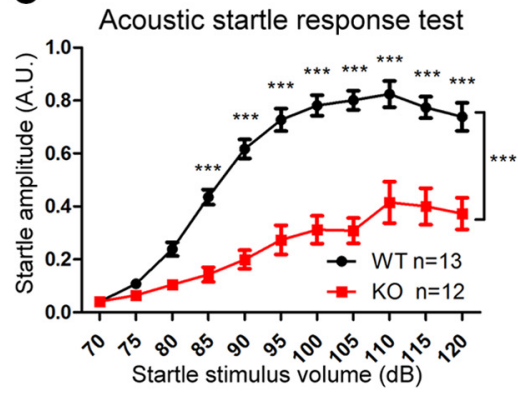

E NOR test

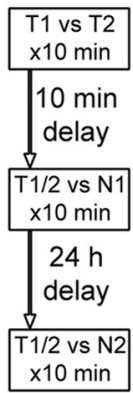

F NOR (10 min delay)

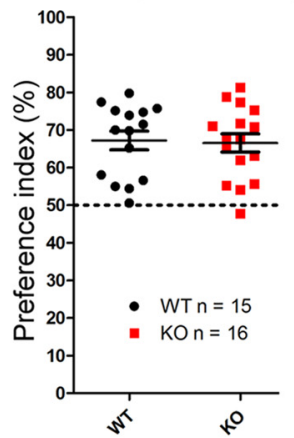

G NOR (24 h delay)

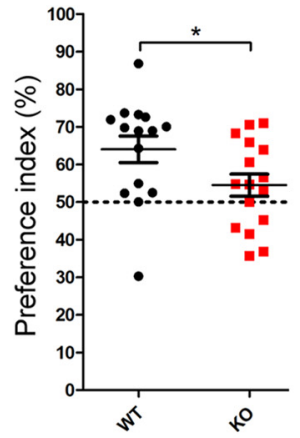

I

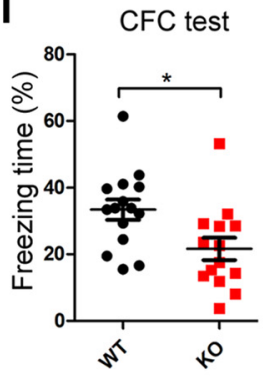

L

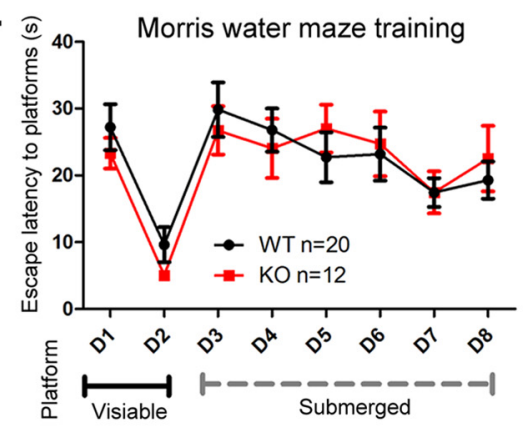

M
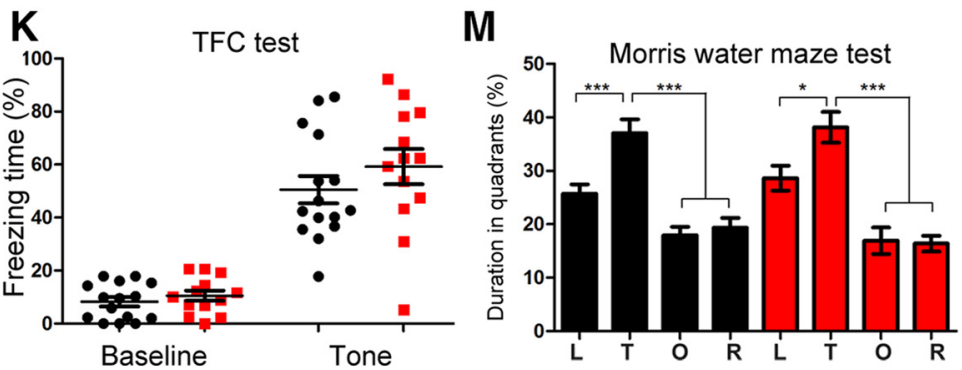

Figure 7. Behavioral characterization of Sorbs $2 \mathrm{KO}$ mice. $\boldsymbol{A}$, Locomotion activity in open-field test and ( $\boldsymbol{B}$ ) anxiety level in elevated-zero maze test were similar between Sorbs $2 \mathrm{KO}$ and WT mice. C, Sorbs $2 \mathrm{KO}$ mice showed dramatically reduced response to stimuli in the acoustic startle response test (two-way ANOVA, startle stimulus volume $\times$ genotype: interaction, $p<0.0001$; effect of genotype, $p<0.0001$; effect of startle stimulus volume, $p<0.0001$; Bonferroni post hoc test: ${ }^{* * *} p<0.0001$; WT: $n=13, \mathrm{~K} 0: n=12$ ). $\boldsymbol{D}$, PPl is significantly impaired in Sorbs2 K0 mice (two-way ANOVA, prepulse stimulus volume $\times$ genotype: interaction, $p<0.0001$; effect of genotype, $p=0.0677$; effect of prepulse stimulus volume, $p<0.0001$; Bonferroni post hoc test: ** $p<0.01$, ${ }^{* * *} p<0.0001$ ). E, Scheme of novel object recognition (NOR) test. Two identical objects (T1 and T2) were used in the training session, and two different novel objects N1 or N2 were exposed to mice in the test session $10 \mathrm{~min}$ or $24 \mathrm{~h}$ after training to assess short-term (10 min) or long-term $(24 \mathrm{~h})$ object recognition memory, respectively. $F$, Short-term object recognition memory is intact in Sorbs 2 K0 mice (WT: $67.21 \pm 2.51 \%, n=15 ; \mathrm{K} 0: 66.56 \pm 2.43 \%, n=16$; two-tailed $t$ test, $p=0.8547$ ). G, Long-term object recognition memory is impaired in Sorbs2 K0 mice (WT: $64.04 \pm 3.54 \%$, $n=15 ; \mathrm{K} 0: 54.52 \pm 2.93 \%, n=16 ;$ two-tailed $t$ test, $\left.{ }^{*} p<0.05\right)$. $\boldsymbol{H}$, Sorbs $2 \mathrm{KO}$ mice behaved similarly as WT during the training of contextual fear conditioning (CFC) task. Percentages of freezing time per $30 \mathrm{~s}$ bin across the training were compared between genotypes. Arrows indicate the delivery of footshocks. I, Sorbs $2 \mathrm{KO}$ mice showed reduced freezing time in CFC test (WT: $33.41 \pm 3.04 \%$, $n=15 ; \mathrm{KO}: 21.61 \pm 3.35 \%, n=14$; two-tailed $t$ test, $\left.{ }^{*} p<0.05\right)$. $J, \boldsymbol{K}$, WT and Sorbs2 $\mathrm{KO}$ mice behaved similarly during the training $(\boldsymbol{J})$ and the memory test $(\boldsymbol{K})$ of toned fear conditioning (TFC) task. B, Baseline; T1-T5 indicate the presence of tones; ITI, intertrial interval. Arrows indicate the delivery of footshocks. $L, M$, Sorbs 2 KO mice showed normal spatial learning and memory as WT mice in Morris water maze test. T, Target quadrant; $L$, adjacent left quadrant; $R$, adjacent right quadrant; 0 , opposite quadrant. Error bars indicate SEM.

nal development and ID. We report here, for the first time, that loss of Sorbs 2 in mice led to reduced dendritic complexity, decreased excitatory synaptic transmission, impaired acoustic startle response, and defective long-term memory. These findings indicate that SORBS2 plays an important role in dendritic development and memory formation. Meanwhile, SORBS2 is also linked to congenital heart disease and cancer metastasis (Roignot and Soubeyran, 2009; Geng et al., 2014), which are likely related 
to the functions of non-neuronal ArgBP2 isoforms. Thus, Sorbs2 mutant mice could be a useful tool to investigate ArgBP2 function in cardiology and oncology research.

nArgBP2, as the only neuronal isoform coded by the Sorbs2 gene, is highly expressed in dendritic growth cones and spines of cultured neurons. In support of nArgBP2 localization at dendritic growth cones in vivo, we observed enriched nArgBP2 localization in the outer one-third of the molecular layer of the DG during development, which corresponds to the location of outgrowing tips of DG granule cell dendrites (Rahimi and Claiborne, 2007). In Sorbs $2 \mathrm{KO}$ mice, we found that the dendritic complexity of DG granule cells was dramatically reduced (Fig. $5 \mathrm{H}-\mathrm{K}$ ), whereas the lamination of the DG molecular layer (Fig. 4C) and spine density of OML (Fig. $5 L, M$ ) were all comparable with WT. These results argue for a critical role of nArgBP2 in dendritic development of DG granule cells. Interestingly, reduced dendritic complexity phenotype of DG granule cells has also been observed in several other mouse models for intellectual disability (Chen et al., 2012; Powell et al., 2012; Dang et al., 2014), suggesting that defects in dendritic development might be a potential common pathology.

ArgBP2/nArgBP2 has been reported to interact with multiple actin regulatory proteins, including Arg, c-Abl, Vinculin, Paxillin, WAVE, c-Cbl, Pyk2, PKB, PAK1, $\alpha$-actinin, 14-3-3, and SAPAP (Wang et al., 1997; Kawabe et al., 1999; Haglund et al., 2004; Cestra et al., 2005; Rönty et al., 2005; Yuan et al., 2005; Anekal et al., 2015), which can be generally grouped into cell adhesion molecules and regulators and effectors of small GTPases. Among them, Paxillin is a signal transduction adaptor protein that recruits regulatory and structural proteins to cell adhesion sites that bind to the extracellular matrix (Deakin and Turner, 2008). Previous studies reported that Paxillin localization and phosphorylation, which are critical for its function, were impaired by overexpression or knockdown of ArgBP2 in nonneuronal cells (Cestra et al., 2005; Martin et al., 2013). It is possible that this interaction of ArgBP2 and Paxillin, direct or indirect, may play a similar role in neuronal cells. Another important signaling pathway regulating dendritic development is the small GTPase, such as Rho and Rac. Rac activation promotes dendrite growth and branching, whereas Rho activation inhibits dendritic development (Negishi and Katoh, 2005; Vadodaria et al., 2013). The ArgBP2/nArgBP2 interaction partner $\mathrm{Cbl}$ and Arg have been reported to regulate Rac and RhoA activities, respectively (Scaife et al., 2003; Sfakianos et al., 2007). Therefore, future studies of Rac and RhoA activities in Sorbs2 KO mice may elucidate how nArgBP2 might coordinate these two signaling pathways during dendritic development. Additionally, our study showed that the NSE of Sorbs2 gene can promote nArgBP2 targeting into dendritic spines. Thus, the identification of binding partners to this exon in future studies may provide new insights into the unique function of $\mathrm{nArgBP} 2$ in the brain.

$\mathrm{nArgBP} 2$ is highly expressed in many brain regions, including cortex, amygdala, and DG. We noticed that Sorbs 2 KO mice showed a specific deficit in contextual fear memory but not in toned fear memory, suggesting that $\mathrm{nArgBP} 2$ may play a more important role in hippocampus than in the amygdala (Phillips and LeDoux, 1992; Maren et al., 2013). Although our current cellular and electrophysiological studies were focused on the DG, some of the behavioral defects, such as novel object recognition and sensorimotor gating, could also involve cortical dysfunction. Future studies combining Sorbs2 floxed mice with regional and cell-type specific expression of Cre recombinase will be able to dissect the neural circuits underlying these behavioral phenotypes.

\section{References}

American Psychiatric Association (2013) Diagnostic and statistical manual of mental disorders, 5th Ed. Washington, DC: American Psychiatric Association.

Anagnostaras SG, Wood SC, Shuman T, Cai DJ, LeDuc AD, Zurn KR, Zurn JB, Sage JR, Herrera GM (2010) Automated assessment of Pavlovian conditioned freezing and shock reactivity in mice using the VideoFreeze system. Front Behav Neurosci 4:pii158. CrossRef Medline

Anekal PV, Yong J, Manser E (2015) Arg kinase binding protein 2 (ArgBP2) interaction with alpha-actinin and actin stress fibres inhibits cell migration. J Biol Chem 290:2112-2125. CrossRef Medline

Antunes M, Biala G (2012) The novel object recognition memory: neurobiology, test procedure, and its modifications. Cogn Process 13:93-110. CrossRef Medline

Barak B, Okun E, Ben-Simon Y, Lavi A, Shapira R, Madar R, Wang Y, Norman E, Sheinin A, Pita MA, Yizhar O, Mughal MR, Stuenkel E, van Praag H, Mattson MP, Ashery U (2013) Neuron-specific expression of tomosyn 1 in the mouse hippocampal dentate gyrus impairs spatial learning and memory. Neuromol Med 15:351-363. CrossRef Medline

Bliss TV, Collingridge GL (1993) A synaptic model of memory: long-term potentiation in the hippocampus. Nature 361:31-39. CrossRef Medline

Cai D, Cohen KB, Luo T, Lichtman JW, Sanes JR (2013) Improved tools for the Brainbow toolbox. Nat Methods 10:540-547. CrossRef Medline

Castellani CA, Melka MG, Gui JL, O’Reilly RL, Singh SM (2015) Integration of DNA sequence and DNA methylation changes in monozygotic twin pairs discordant for schizophrenia. Schizophr Res 169:433-440. CrossRef Medline

Cestra G, Toomre D, Chang S, De Camilli P (2005) The Abl/Arg substrate ArgBP2/nArgBP2 coordinates the function of multiple regulatory mechanisms converging on the actin cytoskeleton. Proc Natl Acad Sci U S A 102:1731-1736. CrossRef Medline

Chen CY, Tsai MS, Lin CY, Yu IS, Chen YT, Lin SR, Juan LW, Chen YT, Hsu HM, Lee LJ, Lin SW (2012) Rescue of the genetically engineered Cul4b mutant mouse as a potential model for human X-linked mental retardation. Hum Mol Genet 21:4270-4285. CrossRef Medline

Dang V, Medina B, Das D, Moghadam S, Martin KJ, Lin B, Naik P, Patel D, Nosheny R, Wesson Ashford J, Salehi A (2014) Formoterol, a longacting beta 2 adrenergic agonist, improves cognitive function and promotes dendritic complexity in a mouse model of Down syndrome. Biol Psychiatry 75:179-188. CrossRef Medline

Deakin NO, Turner CE (2008) Paxillin comes of age. J Cell Sci 121:24352444. CrossRef Medline

Förster E, Zhao S, Frotscher M (2006) Laminating the hippocampus. Nat Rev Neurosci 7:259-267. CrossRef Medline

Foust KD, Nurre E, Montgomery CL, Hernandez A, Chan CM, Kaspar BK (2009) Intravascular AAV9 preferentially targets neonatal neurons and adult astrocytes. Nat Biotechnol 27:59-65. CrossRef Medline

Fromer M, Pocklington AJ, Kavanagh DH, Williams HJ, Dwyer S, Gormley P, Georgieva L, Rees E, Palta P, Ruderfer DM, Carrera N, Humphreys I, Johnson JS, Roussos P, Barker DD, Banks E, Milanova V, Grant SG, Hannon E, Rose SA, et al. (2014) De novo mutations in schizophrenia implicate synaptic networks. Nature 506:179-184. CrossRef Medline

Geng J, Picker J, Zheng Z, Zhang X, Wang J, Hisama F, Brown DW, Mullen MP, Harris D, Stoler J, Seman A, Miller DT, Fu Q, Roberts AE, Shen Y (2014) Chromosome microarray testing for patients with congenital heart defects reveals novel disease causing loci and high diagnostic yield. BMC Genomics 15:1127. CrossRef Medline

Glover CP, Bienemann AS, Heywood DJ, Cosgrave AS, Uney JB (2002) Adenoviral-mediated, high-level, cell-specific transgene expression: a SYN1-WPRE cassette mediates increased transgene expression with no loss of neuron specificity. Mol Ther 5:509-516. CrossRef Medline

Gradinaru V, Mogri M, Thompson KR, Henderson JM, Deisseroth K (2009) Optical deconstruction of parkinsonian neural circuitry. Science 324: 354-359. CrossRef Medline

Grover LM, Kim E, Cooke JD, Holmes WR (2009) LTP in hippocampal area CA1 is induced by burst stimulation over a broad frequency range centered around delta. Learn Mem 16:69-81. CrossRef Medline

Gunaydin LA, Yizhar O, Berndt A, Sohal VS, Deisseroth K, Hegemann P (2010) Ultrafast optogenetic control. Nat Neurosci 13:387-392. CrossRef Medline

Haglund K, Ivankovic-Dikic I, Shimokawa N, Kruh GD, Dikic I (2004) Recruitment of Pyk2 and $\mathrm{Cbl}$ to lipid rafts mediates signals important for 
actin reorganization in growing neurites. J Cell Sci 117:2557-2568. CrossRef Medline

Hancock JF, Cadwallader K, Paterson H, Marshall CJ (1991) A CAAX or a CAAL motif and a 2nd signal are sufficient for plasma-membrane targeting of Ras proteins. EMBO J 10:4033-4039. Medline

Heyer MP, Pani AK, Smeyne RJ, Kenny PJ, Feng G (2012) Normal midbrain dopaminergic neuron development and function in miR-133b mutant mice. J Neurosci 32:10887-10894. CrossRef Medline

Jasnow AM, Schulkin J, Pfaff DW (2006) Estrogen facilitates fear conditioning and increases corticotropin-releasing hormone mRNA expression in the central amygdala in female mice. Horm Behav 49:197-205. CrossRef Medline

Kaech S, Banker G (2006) Culturing hippocampal neurons. Nat Protoc 1:2406-2415. CrossRef Medline

Kawabe H, Hata Y, Takeuchi M, Ide N, Mizoguchi A, Takai Y (1999) nArgBP2, a novel neural member of ponsin/ArgBP2/vinexin family that interacts with synapse-associated protein 90/postsynaptic density-95associated protein (SAPAP). J Biol Chem 274:30914-30918. CrossRef Medline

Kervestin S, Jacobson A (2012) NMD: a multifaceted response to premature translational termination. Nat Rev Mol Cell Bio 13:700-712. CrossRef Medline

Kim IH, Racz B, Wang H, Burianek L, Weinberg R, Yasuda R, Wetsel WC, Soderling SH (2013) Disruption of Arp2/3 results in asymmetric structural plasticity of dendritic spines and progressive synaptic and behavioral abnormalities. J Neurosci 33:6081-6092. CrossRef Medline

Kim JH, Lee SR, Li LH, Park HJ, Park JH, Lee KY, Kim MK, Shin BA, Choi SY (2011) High cleavage efficiency of a 2A peptide derived from porcine teschovirus-1 in human cell lines, zebrafish and mice. PLoS One 6:e18556. CrossRef Medline

Kioka N, Ueda K, Amachi T (2002) Vinexin, CAP/ponsin, ArgBP2: a novel adaptor protein family regulating cytoskeletal organization and signal transduction. Cell Struct Funct 27:1-7. CrossRef Medline

Krueger DD, Osterweil EK, Chen SP, Tye LD, Bear MF (2011) Cognitive dysfunction and prefrontal synaptic abnormalities in a mouse model of fragile X syndrome. Proc Natl Acad Sci U S A 108:2587-2592. CrossRef Medline

Laplagne DA, Esposito MS, Piatti VC, Morgenstern NA, Zhao CM, van Praag H, Gage FH, Schinder AF (2006) Functional convergence of neurons generated in the developing and adult hippocampus. PLoS Biol 4:2349-2360. CrossRef Medline

Lois C, Hong EJ, Pease S, Brown EJ, Baltimore D (2002) Germline transmission and tissue-specific expression of transgenes delivered by lentiviral vectors. Science 295:868-872. CrossRef Medline

Luo L (2002) Actin cytoskeleton regulation in neuronal morphogenesis and structural plasticity. Annu Rev Cell Dev Biol 18:601-635. CrossRef Medline

Maren S, Phan KL, Liberzon I (2013) The contextual brain: implications for fear conditioning, extinction and psychopathology. Nat Rev Neurosci 14:417-428. CrossRef Medline

Markus EJ, Zecevic M (1997) Sex differences and estrous cycle changes in hippocampus-dependent fear conditioning. Psychobiology 25:246-252.

Martin M, Geudens I, Bruyr J, Potente M, Bleuart A, Lebrun M, Simonis N, Deroanne C, Twizere JC, Soubeyran P, Peixoto P, Mottet D, Janssens V, Hofmann WK, Claes F, Carmeliet P, Kettmann R, Gerhardt H, Dequiedt F (2013) PP2A regulatory subunit Balpha controls endothelial contractility and vessel lumen integrity via regulation of HDAC7. EMBO J 32: 2491-2503. CrossRef Medline

Murase K, Ito H, Kanoh H, Sudo K, Iwamoto I, Morishita R, Soubeyran P, Seishima M, Nagata K (2012) Cell biological characterization of a multidomain adaptor protein, ArgBP2, in epithelial NMuMG cells, and identification of a novel short isoform. Med Mol Morphol 45:22-28. CrossRef Medline

Negishi M, Katoh H (2005) Rho family GTPases and dendrite plasticity. Neuroscientist 11:187-191. CrossRef Medline

Nishimura-Akiyoshi S, Niimi K, Nakashiba T, Itohara S (2007) Axonal netrin-Gs transneuronally determine lamina-specific subdendritic segments. Proc Natl Acad Sci U S A 104:14801-14806. CrossRef Medline

Osumi N, Guo N, Matsumata M, Yoshizaki K (2015) Neurogenesis and sensorimotor gating: bridging a microphenotype and an endophenotype. Curr Mol Med 15:129-137. CrossRef Medline

Pavlowsky A, Chelly J, Billuart P (2012) Emerging major synaptic signaling pathways involved in intellectual disability. Mol Psychiatry 17:682-693. CrossRef Medline
Peça J, Feliciano C, Ting JT, Wang WT, Wells MF, Venkatraman TN, Lascola CD, Fu ZY, Feng GP (2011) Shank3 mutant mice display autistic-like behaviours and striatal dysfunction. Nature 472:437-442. CrossRef Medline

Phillips RG, LeDoux JE (1992) Differential contribution of amygdala and hippocampus to cued and contextual fear conditioning. Behav Neurosci 106:274-285. CrossRef Medline

Powell AD, Gill KK, Saintot PP, Jiruska P, Chelly J, Billuart P, Jefferys JG (2012) Rapid reversal of impaired inhibitory and excitatory transmission but not spine dysgenesis in a mouse model of mental retardation. J Physiol 590:763-776. CrossRef Medline

Rahimi O, Claiborne BJ (2007) Morphological development and maturation of granule neuron dendrites in the rat dentate gyrus. Prog Brain Res 163:167-181. CrossRef Medline

Rodriguez A, Ehlenberger DB, Dickstein DL, Hof PR, Wearne SL (2008) Automated three-dimensional detection and shape classification of dendritic spines from fluorescence microscopy images. PLoS One 3:e1997. CrossRef Medline

Roignot J, Soubeyran P (2009) ArgBP2 and the SoHo family of adapter proteins in oncogenic diseases. Cell Adh Migr 3:167-170. CrossRef Medline

Rönty M, Taivainen A, Moza M, Kruh GD, Ehler E, Carpen O (2005) Involvement of palladin and alpha-actinin in targeting of the Abl/Arg kinase adaptor ArgBP2 to the actin cytoskeleton. Exp Cell Res 310:88-98. CrossRef Medline

Rossi MR, DiMaio MS, Xiang B, Lu K, Kaymakcalan H, Seashore M, Mahoney MJ, Li P (2009) Clinical and genomic characterization of distal duplications and deletions of chromosome 4q: study of two cases and review of the literature. Am J Med Genet A 149A:2788-2794. CrossRef Medline

Scaife RM, Courtneidge SA, Langdon WY (2003) The multi-adaptor protooncoprotein $\mathrm{Cbl}$ is a key regulator of Rac and actin assembly. J Cell Sci 116:463-473. CrossRef Medline

Sfakianos MK, Eisman A, Gourley SL, Bradley WD, Scheetz AJ, Settleman J, Taylor JR, Greer CA, Williamson A, Koleske AJ (2007) Inhibition of rho via arg and p190RhoGAP in the postnatal mouse hippocampus regulates dendritic spine maturation, synapse and dendrite stability, and behavior. J Neurosci 27:10982-10992. CrossRef Medline

Vadodaria KC, Brakebusch C, Suter U, Jessberger S (2013) Stage-specific functions of the small rho GTPases Cdc42 and Racl for adult hippocampal neurogenesis. J Neurosci 33:1179-1189. CrossRef Medline

van Bokhoven H (2011) Genetic and epigenetic networks in intellectual disabilities. Annu Rev Genet 45:81-104. CrossRef Medline

van Goethem NP, Rutten K, van der Staay FJ, Jans LA, Akkerman S, Steinbusch HW, Blokland A, van't Klooster J, Prickaerts J (2012) Object recognition testing: rodent species, strains, housing conditions, and estrous cycle. Behav Brain Res 232:323-334. CrossRef Medline

Vorhees CV, Williams MT (2006) Morris water maze: procedures for assessing spatial and related forms of learning and memory. Nat Protoc 1:848-858. CrossRef Medline

Wang B, Golemis EA, Kruh GD (1997) ArgBP2, a multiple Src homology 3 domain-containing, Arg/Abl-interacting protein, is phosphorylated in $\mathrm{v}$-Abl-transformed cells and localized in stress fibers and cardiocyte Z-disks. J Biol Chem 272:17542-17550. CrossRef Medline

Welch JM, Wang D, Feng G (2004) Differential mRNA expression and protein localization of the SAP90/PSD-95-associated proteins (SAPAPs) in the nervous system of the mouse. J Comp Neurol 472:24-39. CrossRef Medline

Welch JM, Lu J, Rodriguiz RM, Trotta NC, Peça J, Ding JD, Feliciano C, Chen M, Adams JP, Luo J, Dudek SM, Weinberg RJ, Calakos N, Wetsel WC, Feng G (2007) Cortico-striatal synaptic defects and OCD-like behaviours in Sapap3-mutant mice. Nature 448:894-900. CrossRef Medline

Witter MP (2007) The perforant path: projections from the entorhinal cortex to the dentate gyrus. Prog Brain Res 163:43-61. CrossRef Medline

Yardeni T, Eckhaus M, Morris HD, Huizing M, Hoogstraten-Miller S (2011) Retro-orbital injections in mice. Lab Anim (NT) 40:155-160. CrossRef Medline

Yuan ZQ, Kim D, Kaneko S, Sussman M, Bokoch GM, Kruh GD, Nicosia SV, Testa JR, Cheng JQ (2005) ArgBP2gamma interacts with Akt and p21activated kinase-1 and promotes cell survival. J Biol Chem 280:21483-21490. CrossRef Medline

Zhang Q, Wang F, Cao J, Shen Y, Huang Q, Bao L, Zhu X (2009) Nudel promotes axonal lysosome clearance and endo-lysosome formation via dynein-mediated transport. Traffic 10:1337-1349. CrossRef Medline 